The University of Southern Mississippi The Aquila Digital Community

Faculty Publications

8-7-2019

\title{
Reports of Recovered Memories of Childhood Abuse in Therapy in France
}

Olivier Dodier

Université Clermont Auvergne

Lawrence Patihis

University of Southern Mississippi, l.patihis@usm.edu

Mélany Payoux

Université de Nantes

Follow this and additional works at: https://aquila.usm.edu/fac_pubs

Part of the Psychology Commons

\section{Recommended Citation}

Dodier, O., Patihis, L., Payoux, M. (2019). Reports of Recovered Memories of Childhood Abuse in Therapy in France. Memory, 27(9), 1283-1298.

Available at: https://aquila.usm.edu/fac_pubs/16537 


\title{
Reports of Recovered Memories of Childhood Abuse in Therapy in France
}

\author{
Olivier Dodier $^{\mathrm{a}^{*}}$, Lawrence Patihis $^{\mathrm{b}}, \&$ Mélany Payoux ${ }^{\mathrm{c}}$ \\ ${ }^{\mathrm{a}}$ LAPSCO, Université Clermont Auvergne, Clermont-Ferrand, France; ${ }^{\mathrm{b}}$ Department of \\ Psychology, University of Southern Mississippi, USA, ${ }^{c}$ Laboratoire de Psychologie des Pays \\ de la Loire, Université de Nantes, France
}

Accepted for publication in Memory

*Corresponding author: Olivier Dodier, Université Clermont Auvergne, CNRS, LAPSCO, 34 Avenue Carnot, F-63000, Clermont-Ferrand, France. E-mail address: olivier.dodier@uca.fr 


\begin{abstract}
Recovered memories of abuse in therapy are especially controversial if the clients were not aware they were abused before therapy. In the past, such memory recovery has led to legal action, as well as a debate about whether such memories might be repressed, forgotten, or false memories. More than two decades after the height of the controversy, it is unclear to what degree such memories are still recovered today, and to what extent it occurs in France. In our French survey of 1312 participants $\left(M_{\mathrm{age}}=33 ; 53 \%\right.$ female $), 551$ reported having done therapy at some point. Of that 551, $33(6 \%)$ indicated they had recovered memories of abuse in therapy that they did not know about before therapy. Sexual abuse was the most commonly reported type that was recovered in therapy (79\%). As in past research, discussing the possibility of repressed memories with therapists was associated with reports of recovered memories of abuse. Surprisingly, memory recovery occurred just as much in behavioural and cognitive therapies as it did in therapies focused on trauma. We found recovered memories in a proportion of clients who began therapy recently. Recovered memories in therapy appears to be an ongoing concern in France.
\end{abstract}

Keywords: repressed memory, recovered memory, trauma, abuse, psychotherapy, memory war, recovered memory therapy, psychoanalysis 


\section{Reports of Recovered Memories of Childhood Abuse in Therapy in France}

In May 2017, a French therapist was convicted of implanting false memories of abuse into several of her clients (Agence France Presse, 2017). One of the therapists' clients told investigators that her therapist led him to remember intrauterine memories of her mother trying to abort him with knitting needles. As a consequence of this therapy, the client became estranged from his family and paid tens of thousands of euros to the therapist to treat the resulting trauma. Although this is an extreme case of highly unlikely false memories, many other cases of implanted false memories that were much more plausible have been identified and discussed (e.g., Loftus, 1993; Patihis \& Younes Burton, 2015; but see Pezdek, BlandonGitlin, \& Gabbay, 2006, for a critique of implausible false memory implantation).

Such practice is sometimes rooted in a belief in the concept of repression. This posits that when an event is too shocking for an individual, the memory of the event is pushed below consciousness, becoming unavailable for retrieval. Freud (1893-1895/1953) was one of the first to develop the hypothesis of repression. Today, it seems that this belief is still widely held among the general public (e.g., Dodier \& Payoux, 2017; Patihis, Ho, Tingen, Lilienfeld, \& Loftus, 2014), law enforcement (e.g., Dodier, Tomas, Payoux, \& Elissalde, 2019), and clinicians (e.g., Dodier, Melinder, Otgaar, Payoux, \& Magnussen, in press; Dodier \& Payoux, 2017; Melinder \& Magnussen, 2015; Otgaar et al., in press; Patihis, Ho, et al., 2014; Yapko, 1994). The scientific validity of this mechanism was the subject of much debate in the literature in the 1990s, often referred to as "memory wars" (see Dodier, 2019, for a summary of this debate). However, a recent literature review showed that the debate about the scientific validity of repression was still ongoing, and that the term "repression" no longer seems to be used in the scientific literature-with some arguing that it has been replaced by the term dissociative amnesia (Otgaar et al., in press). If some of the public and some clinicians do 
believe in the concept of repressed memories, then to what extent does that manifest itself in the recovery of purportedly repressed memories in therapy?

Patihis and Pendergrast (2019) reported survey data of a large US sample showing that $8-9 \%$ of the total sample reported having discussed the possibility of repressed memories with their therapist, and 4-5\% reported having recovered memories of childhood abuse during the course of therapy. After extrapolating to the overall US population (i.e., 20 years old and more) population, they estimated that this could affect between approximately 9 and 12 million US individuals. Focusing only on participants who had undergone therapy, these results amounted to about $20 \%$ and $11 \%$, respectively. This is an important issue to explore, because such recovered memory therapies are deemed as potentially harmful: it may lead to social consequences (e.g., estrangement from family and acquaintances; e.g., Loftus, 1997), legal consequences (e.g., prosecutions; see Loftus, 1993), or adverse psychological consequences (e.g., trauma; see Lilienfeld, 2007).

In this study we attempted to replicate the Patihis and Pendergrast's study (2019) with a French sample. Such replication in France is relevant because clinical practice in France has a strong historical connection with psychoanalysis. Considering that repression is strongly linked to psychoanalysis and psychoanalytical practice, we wanted to know to what extent French therapists engage in practices aimed at helping individuals recover allegedly repressed memories. Therefore, our objectives were threefold: first, we wanted to determine the incidence rate of recovered memories during therapy in France. Second, we wanted to evaluate the preliminary findings of Shaw and Vredeveldt (2019) that the recovered memory debate is still ongoing in Europe, including France (p. 28). Third, we wanted to respond to the suggestion made by Patihis and Pendergrast (2019) to ask participants follow up questions to clarify what they meant when reporting recovered memories they did not know about before commencing therapy. In other words, this last objective was aimed at identifying potential 
false positives (and false negatives) among participants' claims of child abuse memories recovered during therapy.

\section{The Scientific Status of Repressed Memories}

Patihis and Pendergrast (2019) argued that the idea that individuals might repress traumatic memories appears to have become enshrined in the $5^{\text {th }}$ edition of the Diagnostic and Statistical Manual of Mental Disorders (i.e., under the name of dissociative amnesia; American Psychiatric Association, 2013, see also Otgaar et al., in press). Indeed, some 21st century authors still appear to adopt the view that trauma memories can be stored and become inaccessible for a long period of time — sometimes decades — before it becomes recoverable (Brand et al., 2018; Dalenberg et al., 2012; DePrince et al., 2012; see also Dodier, 2019, for a review of the evolution of the 21 st century publications related to the recovered memory debate).

However, criticism has been voiced against this concept of recovered memories. According to critics, there was not enough scientific evidence to support the existence of repression — or dissociative amnesia (e.g., Dodier \& Tomas, 2019; Holmes, 1990; Lynn et al., 2014; Loftus, \& Joslyn, \& Polage, 1998; McNally \& Geraerts, 2009; Merckelbach \& Patihis, 2018; Otgaar et al., in press; Patihis, Ho et al., 2014; Patihis, Ho, Loftus, \& Herrera, 2018; Patihis, Otgaar, \& Merckelbach, in press; but for contrasting work utilizing the trauma model of dissociative amnesia, see Bremner, Krystal, Charney, \& Southwick, 1996; Lanius, Brand, Vermetten, Frewen, \& Spiegel, 2012). In support of these criticisms, several studies have highlighted that traumatic events are generally well remembered (e.g., Sachschal, Woodward, Wichelmann, Haag, \& Ehlers, in press), even many years later (Goodman et al., 2003), and that there is a positive relationship between the severity of the offence and the memory of these experiences (Alexander et al., 2005). In addition, a recent meta-analysis revealed that high stress in encoding was beneficial to the accuracy of memories, if the stress was directly 
related to the material (e.g., event) being retrieved (Shields, Sazma, McCullough, \& Yonelinas, 2017). Of course, challenging memory repression as a valid mechanism does not imply that all traumatic recovered memories are necessarily false. Some of them may reflect an actual event, but may be still explained by mechanisms other than repression. Several alternative mechanisms have been advanced by scholars, such as ordinary forgetting in cases where the abuse was not experienced as traumatic at the time it occurred. (e.g., Engelhard, McNally, \& van Schie, 2019; McNally \& Geraerts, 2009), not thinking about the event (McNally \& Geraerts, 2009), or explanatory models of the influence of stress on memory (e.g., Deffenbacher, Bornstein, Penrod, \& McGorty, 2004; see Dodier \& Tomas, 2019). Proponents of repressed memories generally draw upon three research paradigms to assert the existence of this mechanism. The first is the Think/No think paradigm, which consists of instructing participants to either think about a word previously learned or not to think about it. Studies have shown that words in the "No think" condition are less recalled than words in the "Think" condition (e.g., Anderson \& Green, 2001). It is difficult to draw an analogy between the results obtained using this paradigm and repression for several reasons: (i) the results are not always replicated (Bulevitch, Roediger, Balota, \& Butler, 2006); (ii) it seems that the forgotten words do not manifest and do not affect future thoughts (Wang, Luppi, Fawcett, \& Anderson, 2019)—which would be one of psychological consequences repression (Freud, 1915, 1966; Pennebaker, 1997)—; (iii) there would be no evidence for such suppression-induced forgetting in clinical samples (e.g., PTSD, depression; Stramaccia, Rischer, Fawcett, Benoit, submitted; but see Hulbert \& Anderson, 2018, who argued that there are stronger Think/No Think effects in people reporting an experience of trauma); and (iv) the words are forgotten as a result of an instruction from a third party (e.g., experimenter). The second paradigm is the direct forgetting paradigm, in which participants are instructed to inhibit memory retrieval for trauma-related words (e.g., DePrince et al., 2012). Nevertheless, 
some research has found weak evidence that there is increased motivated forgetting of trauma related words in dissociated or traumatised participants (Patihis \& Place, 2018). Third, proponents generally rely on prospective studies where participants with history of childhood abuse are asked whether they experienced a period of time during which they had no memories of the abuse. In these studies, substantial amounts of participants reported a period of time with no memories of the abuse (e.g., Briere \& Conte, 1993; Elliott, 1997; Elliot \& Briere, 1995; Williams, 1995). Again, it is difficult to consider these studies as sound evidence of the reality of repression. In addition to the fact that these statements are not systematically corroborated, these periods of time without memories have been explained more parsimoniously (e.g., McNally \& Geraerts, 2009; Loftus, 1994). In sum, the limitations we described have led sceptical researchers to conclude that repression is a theory "devoid of convincing empirical support” (Engelhard et al., 2019, p. 92).

\section{Recovered Memory Therapy and Beliefs about Repressed Memory}

Although repression is not a sufficiently proven phenomena and scepticism is abound in the scientific literature (Dodier, 2019), several types of psychotherapies are partly aimed at helping patients to recover repressed memories. As Patihis and Pendergrast (2019) pointed out, it is very rare for therapists to explicitly state that the objective of their therapeutic techniques is to dig up memories buried in the unconscious. They also pointed out that while some therapies have the explicit objective of helping traumatized individuals manage their traumas (e.g., EMDR, Shapiro, 2018), others that do not have this main objective (e.g., modern psychoanalytic or psychodynamic therapies, Shedler, 2010; cognitive and behavioral therapies, Beck, 1970) may focus on past trauma (e.g., Cohen, Mannarino, Kliethermes, \& Murray, 2012), sometimes relying on non-evidence-based techniques (Hipol \& Deacon, 2013). What is the risk associated with this focus on past trauma? 
Research on memory distortion can bring helpful insights. Decades of research have highlighted the fact that memory is a reconstructive process and that it is particularly malleable and sensitive, especially to external influences (e.g., suggestions). It is today possible to affirm that the misinformation effect (i.e., the implementation in one's memory of post-experienced event encoded information) is one of the most robust findings in memory research (Loftus, 2005). Research has shown that it is also possible, under certain circumstances, to develop false memories for entire events (e.g., Loftus and Pickrell, 1995), including criminal events (Shaw \& Porter, 2015; but see also Wade, Garry, \& Pezdeck, 2018; Shaw, 2018). Systematic reviews of false memory research have seen rates ranging from $15 \%$ (Brewin \& Andrews, 2017; but see Otgaar, Merckelbach, Jelicic, \& Smeets, 2017; Nash, Wade, Garry, Loftus, \& Ost, 2017) to 30\% (Scoboria et al., 2017) of participants developing false memories.

The question that now arises is what therapeutic techniques could lead to the development of false memories. Besides the implementation of misleading post-event information, other suggestive techniques sometimes used in therapy have been identified as potentially harmful for patients, in that they are accompanied by increased risks of creating false memories (see Lilienfeld, 2007; Lynn, Lock, Loftus, Krackow, \& Lilienfeld, 2003). Examples include guided imagery (e.g., Garry, Manning, Loftus, \& Sherman, 1996), hypnosis (Laurence \& Perry, 1983) or dream interpretation (Mazzoni, Loftus, Seitz, \& Lynn, 1999). Recent works found that lateral eye movements - a technique that is central to EMDR therapy - increased false memory rates in a misinformation paradigm (Houben, Otgaar, Roelofs, \& Merckelbach, 2018; but see Calvillo \& Emami, in press; van Schie \& Leer, in press, for failed replications). A recent meta-analysis also revealed the positive relationship between PTSD, history of trauma and depression and levels of false memory for emotional associative material (Otgaar, Murris, Howe, Merckelbach, 2017). The authors of this meta- 
analysis focused on spontaneous false memories (e.g., elicited using a DRM task) and not on suggestion-induced false memories. But their findings suggest that any therapeutic techniques suggesting trauma-related information to, for instance, depressive patients could lead them to develop false memories.

However, we must balance our statements. It is not the focus on past trauma that is necessarily problematic in itself. What is problematic is when this focus is achieved through suggestive methods. Indeed, if open and non-suggestive questions, in the context of a structured clinical interview, allow memories of past abuse to be recovered, they may be less questionable as to their reliability than memories collected using suggestive methods. In this line of thoughts, it has been argued that judicial investigation interview protocols can be used in a clinical setting (Dodier \& Otgaar, in press).

In sum, the risks of distorting memories of personally experienced events, or developing false memories of entire events (or at least false beliefs that these events occurred, see the distinction in Wade et al., 2018) might be high when suggestive techniques are used to recover or modify traumatic memories for therapeutic purposes. These risks could be all the higher as therapists and/or patients believe in the reality of repressed memories. Both the general public (i.e., potential patients) and clinicians (e.g., clinical psychologists, psychiatrists, psychoanalysts) show high rates of adherence to the belief that individuals can repress traumatic memories. Studies in the U.S. have found that between 24\% (Golding, Sanchez, \& Sego, 1996) to 77\% (Patihis, Ho, et al., 2014) of general public samples expressed agreement with items describing repressed memories of traumatic experience. In France, $55 \%$ of a general public sample considered that memories recovered during therapy were all or most true (Dodier \& Payoux, 2017). On the clinician side, the findings are quite similar: 23\% (Yapko, 1994) to 70\% (Ost, Easton, Hope, French, \& Wright, 2017) of clinicians expressed agreement either with the idea of repressed memories per se or with the 
idea that it is possible to recover memories during therapy, and that these memories are generally genuine. These findings appear to be fairly shared in the Western sphere (Dammeyer, Nightingale, \& McCoy, 1997; Magnussen \& Melinder, 2015; Ost et al., 2017; Patihis, Ho, et al., 2014). In accordance with these results, $43 \%$ of French clinicians considered that memories recovered during therapy were all or most true. This rate rose to $52 \%$ for clinicians also serving as expert witnesses. These findings suggest that in France too, rates of reported recovered traumatic memories during therapy might reach concerning levels. Of note, beliefs about repression are much lower in memory researcher samples (see Patihis et al., 2014). This could suggest that the high rates of belief we briefly reviewed above may reflect a poor understanding on the part of clinicians and the public of how memory works.

\section{Present study}

Our main objective of the current study was to determine how frequent people reported recovered memories of childhood abuse during the course of therapy in France. France has very particular affinity with psychoanalytical theories. The popularity of psychoanalysis in France dates back to the 1970s, when behavioural or cognitive-behavioural methods were quite easily considered cold and dedicated to mind control (Amouroux, 2017). Since then, it is well-known that French clinical practice and education has a very strong psychoanalytical culture (Holden, 2005). As a result, psychoanalytical methods and theories (e.g., repression) are widely used by French psychologists and psychiatrists (Combalbert, Andronikof, Armand, Robin, \& Bazex, 2014; Guivarch et al., 2017). Furthermore, as we briefly reviewed, clinicians and the general public in France seem to have little knowledge and false beliefs about how memory works (Dodier, 2018; Dodier \& Payoux, 2017). We therefore have some reason to hypothesize that the proportion of participants reporting memories recovered during therapy may be similar as the amount observed in Patihis and Pendergrast (2019). 


\section{Predictions}

\section{Discussions and Recovered Memories during Therapy}

This research is a French replication of the Patihis and Pendergrast's study (2019). Therefore, the predictions were quite similar. Clinicians and the general public in France easily embrace the theory of repressed memories, but knowledge about memory has progressed and has been taught to younger therapists. Thus, we expected a rather low frequency of discussions on repressed memories between therapists and patients, especially between 2010 and 2018. For the same reasons, we expected less reports of recovered memories between 2010 and 2018 than in previous years.

Although we did not discuss the links between the recovered memories and dissociative identity disorder (DID; see, for instance, Lynn et al., 2014; Lynn et al., in press) in the introduction, we did explore the proportion of participants who reported having recovered memories of abuse and also developed DID in the current study. Patihis and Pendergrast (2019) hypothesized that the prevalence of DID in therapy should have decreased since the 1980s and 1990s, relying on research showing that both DID diagnoses and DID research decreased during these periods. As these conclusions are strongly focused on AngloSaxon country data, and as there are no similar data for France, we consider these analyses to be exploratory.

\section{Therapist and Therapy Types}

We expected that therapies specifically proposing to work on psychological trauma (e.g., EMDR, emotionally focused therapies) would be more associated with (i) reported discussions of repressed memories, as well as (ii) reported memories recovered in therapies, than evidence-based therapies not focusing on past trauma (e.g., cognitive behavioural therapies). In addition, we expected higher rates of reported discussions and recovered memories with psychoanalysis-oriented therapists. 


\section{Abuse Type, Gender, and Context of Recovery}

Reported cases, media coverage, or books and articles focusing on recovered memories also generally focus on childhood sexual and physical abuse (see Bass \& Davis, 1988; Freyd, 1994; for France, see Salmona, 2018). We therefore predicted that a substantial amount of reported recovered memories would involve sexual and physical abuse.

The results of a widely spread survey on sexual violence conducted in France shows that women are significantly more exposed to sexual violence than men, and that 2 out of 5 women have experienced their first sexual abuse before the age of 15 (Debauche et al., 2017). Thus, we expected therapists to discuss more the hypothesis of repressed memories of sexual abuse with women than with men. Similarly, we expected more sexual abuse memories to be recovered in women than in men.

The four most frequently reported memory recovery contexts in Patihis and Pendergrast (2019) were flashbacks, panic attacks, body memories and guided imagery. We then expected similar recovery contexts and, like them, that the memories would be recovered both during and outside the therapy.

\section{Correlates of Recovered Memories}

Given the literature on the importance of external influences (e.g., suggestions and suggestive techniques) we reviewed, we predicted that discussions on repressed memories between therapists and clients would be associated with more reports of recovered memories.

Based on Patihis and Pendergrast's (2019) findings, we expected that it would be frequent for participants who had recovered memories during therapy to have stopped contact with family or acquaintances. We also explored the continuation of these consequences (i.e., whether or not contact was resumed, and to what degree).

Finally, we explored the association between beliefs in repressed memory and in the recovered memory therapies' effectiveness and the report of recovered memories during 
therapy. Because false beliefs regarding how memory works may encourage therapists to rely on unsupported suggestive therapeutic techniques (Lynn, Evans, Laurence, \& Lilienfeld, 2015), and because people entering therapy generally have the motivation to find explanations for their symptoms, making them potentially suggestible (Scoboria et al., 2017), we expected more reports of recovered memories during therapy in participant who believed in repressed memory and in the recovered memory therapies' effectiveness.

\section{Method}

\section{Participants}

In total, 1,492 French adult participants were recruited online via social networks (Twitter or Facebook; see Supplemental Appendix 1). We excluded 180 participants because of incomplete analysis-relevant data (e.g., age, gender, beliefs in repressed memories, etc.) or because we suspected a liberal response bias, leaving our data set for analysis of 1,312 participants (see Supplemental Appendix 4). Their mean age was 33.3 years old $(S D=10.6$; rank $=18-74), 603(46.0 \%$, CI 95\% $=[43.2,48.7])$ reported to be male, 689 reported to be female $(52.5 \%$, CI 95\% $=[49.8,55.2])$, and $20(1.5 \%$, CI 95\% $=[0.9,2.3])$ reported to have another gender (e.g., non-binary).

\section{Materials and Procedure}

The questionnaire (in French), developed and distributed on Qualtrics, was very similar to the one used by Patihis and Pendergrast (2019). It started with an introductory note describing briefly the purpose of the questionnaire, that is to examine psychotherapies and their influence on patients (see Supplemental Appendix 2). Participants were informed that the questionnaire was completely anonymous and that the data would be aggregated to calculate averages, frequencies and trends. Despite the fact that having specified that the survey dealt mainly with psychotherapy presented the risk of motivating mainly participants personally involved in our research topics, a minority of them indicated that they participated 
out of personal interest $(7.2 \%$, CI $95 \%=[5.8,8.5], n=94)$. This is supported by the fact that a majority of participants reported that they never had counselling or psychotherapy.

Participants were then asked whether they had psychotherapy or counselling. If "Yes" was chosen, then a series of follow-up questions were asked. They were first asked to give the characteristics of their therapy: year of beginning, whether it was still in progress or completed (and if so, the year of end), the type of therapist and the type of therapy. For the last two cases, a list was proposed to them with the opportunity to answer "I don't know/am not sure" or "Other".

The following two questions were central to our objectives: "During the course of counselling or therapy, did your therapist ever discuss the possibility that you might have been abused as a child but had repressed the memories?" and "During the course of therapy, did you come to remember being abused as a child, when you had no previous memory of such abuse?" They had the opportunity to answer "Yes," "No," and "I don't know/am not sure." After the question about the discussion on repressed memories, we asked a follow-up question in order to determine who had approached the subject first: the therapist or the client (two other response modalities were proposed: "I can't remember", and "Other"). After the question about recovered memories and contrary to Patihis and Pendergrast (2018), we asked additional follow-up questions. Whether they answered "Yes", "No", or "I don't know/am not sure", they were asked to specify their answer (See Supplemental Appendix 3, questions 3a.1 to $3 a .3)$.

These questions were convenient at three levels: first, we were able to uncover potential false positives and false negatives. Second, we were able to distinguish participants who actually recovered memories they did not have before starting therapy, from those who reappraised continuous memories, and from those who worked with the therapist on continuous memories. Third, it allowed participants who had answered "I don't know/am not 
sure" to provide a more precise answer, which brings the frequency of "I do not know/am not sure" to 0 .

We also asked questions relative to the forms of abuse for which they recovered memories, the age they believed they were when the abuse started, duration of abuse, where and how the abuse was remembered, beliefs of the accuracy of their recovered memories, whether those memories involved DID, whether they cut off of contact with family member (and if so, if they resumed contact), and whether they believed in repressed memories and in the recovered memory therapy's effectiveness.

As in Patihis and Pendergrast (2019), we asked them questions relative to family members' and acquaintances' experiences of recovered memories. For reasons of concision and to maintain the focus of our article on the experiences of the participants, these data are not reported in the present article and will be reported fully in a future article. We are aware that data splitting is generally not recommended. However, this part came after the questions on which we are focusing our study, and therefore could not influence the responses we analysed.

Finally, we asked participants socio-demographic questions and invited them to freely provide comments. Data were collected over two months in September to November 2018. The survey took a mean of 7 min to complete $(S D=12$; median 4$)$. Because more follow-up questions were asked to participants who reported having therapy, we calculate a separate average length of completion for them: $9 \min (S D=9$; median 6$)$.

\section{Results}

\section{Descriptive Analyses}

All raw data (in French) can be accessed at https://osf.io/5m4tx/. Out of the 1,312 participants, $551(42 \%$, CI 95\% $=[39.3,44.7])$ reported that they have ever had counselling or psychotherapy. For 298 of them $(54.1 \%$, CI 95\% $=[49.8,58.3])$, therapy was over, while 
for 253 of them $(45.9 \%$, CI $95 \%=[41.7,50.2])$, therapy was still ongoing at the time of the survey. For those whose therapy was completed, it lasted on average 2.9 years $(S D=3.9$; median 2). For those for whom therapy was still in progress, it had started, at the time of the questionnaire, an average of 5.8 years ago $(S D=7.0$; median 3$)$. The rank of years therapies started was from 1970 to 2018 . In Table 1 are summarized the characteristics of therapies (i.e., therapist type and therapy type) that were the subject of questions in the survey.

Table 1 here

\section{Predictions}

Percentage of therapists discussing repressed memories with their clients. Of the 551 participants who reported to have undergone psychotherapy or counselling, $58(10.5 \%$, CI $95 \%=[8.1,13.4])$ reported that they discussed with their therapist the possibility that they had repressed memories of childhood abuse. This amounts to $4.4 \%(\mathrm{CI} 95 \%=[3.4,5.7])$ of the total sample of 1,312 participants. Figure 1 depicts the frequency of reported discussions between therapists and clients about repressed memories over the years. Interestingly, the first reported discussions occurred in the 90s. Between 1995 and 1999, 5 of the 25 participants $(20 \%$, CI $95 \%=[6.8,40.7])$ who reported that they had therapy declared that they discussed with their therapist the possibility that they had repressed memories of childhood abuse. This is the highest rate up to and including 2018.

No statistical differences were observed in the frequency that therapists discussed repressed memories between those who had completed their therapy $(12.8 \%$, CI 95\% $=[10.0$, 15.6], $n=38$, did discuss repressed memories with their therapist) and those who were still in therapy $(7.9 \%$, CI 95\% $=[5.7,10.2], n=20$, did discuss repressed memories with their therapist), $\chi^{2}(1, N=551)=5.212, p=.074$, Cramer's $\mathrm{V}=0.097$. 


\section{Percentage of participants recovering memories of childhood abuse during the}

course of therapy. Initially, $30(5.4 \%, \mathrm{CI} 95 \%=[3.8,7.7])$ of the 551 participants who reported that they had therapy also reported that they recovered memories of childhood abuse during the course of therapy. This amounted to $2.3 \%(\mathrm{CI} 95 \%=1.5,3.2])$ of the total sample of 1,312 participants. However, after excluding false positives and including false negatives ${ }^{1}$ (see Table 2), 33 participants $(6.0 \%$, CI 95\% $=[4.2,8.3])$ reported recovered memories during therapy. This now amounts to $2.5 \%(\mathrm{CI} 95 \%=[1.7,3.5])$ of the total sample. The mean age they believed they were when the abuse started was 6.8 years old $(S D=3.7)$. Note that all subsequent data concerning memories recovered during therapy will take into account corrections for false positives and false negatives.

Table 2 here

Figure 2 depicts the frequency of reported recovered memories during therapy over the years. As for the discussions between therapists and clients, the first reported recovered memories occurred in the 90 s. The highest rate up to and including 2018 was reached between 2000 and 2004: 6 of the 69 participants $(8.7 \%$, CI 95\% $=[3.3,18.0])$ who reported that they had therapy also reported that they remembered childhood abuse in therapy of which they were not previously aware.

No statistical differences were observed in reported recovered memories between those who had completed their therapy $(5.0 \%$, CI $95 \%=[3.2,6.8], n=15$, reported recovered memories) and those who were still in therapy $(7.1 \%$, CI 95\% $=[5.0,9.2], n=18$, did reported recovered memories $), \chi^{2}(1, N=551)=1.052, p=.305$, Cramer's V $=0.044$.

Interestingly, we found that $27(4.9 \%$, CI $95 \%=[3.3,7.0])$ of the 551 participants who had therapy reported that, in fact, they reappraised childhood events as abuse. We also found

\footnotetext{
${ }^{1}$ Those exclude were those who initially indicated yes, but revealed in follow-up questions that the memory recovery had not involved memories that were completely unknown about before therapy
} 
that 71 of them $(12.9 \%$, CI $95 \%=[10.2,16.0])$ reported that they worked on continuous memories of childhood abuse with their therapist.

Figure 2 here

\section{Percentage of participants who recovered memories of childhood abuse who also}

reported that they developed DID. Of the 33 participants who reported that they recovered childhood abuse memories during therapy, $4(12.1 \%$, CI $95 \%=[3.4,28.2])$ also reported that they suffered from MPD/DID. This represents $0.3 \%(C I 95 \%=[0.1,0.8])$ of the total sample of 1,312 participants. In view of the very small number of cases being reported and for the purpose of concision, no further analysis on this matter will be presented in the article.

Associated therapist and therapy types. Table 3 shows the frequency of discussions about repressed memories by therapist and therapy types. The therapists who discussed repressed memories the most with their clients were psychiatrists who also acted as psychoanalysts $(14.6 \%$, CI 95\% $=[6.1,27.8], n=7)$. Those who discussed it the least were psychologists who also acted as psychoanalysts $(6.3 \%$, CI 95\% $=[1.8,15.5], n=4)$. The type of therapy the most associated with discussion around repressed memories was Behavioral Therapy $(22.5 \%$, CI 95\% $=10.8,38.5], n=9)$, while the least associated was Emotion Focused Therapy $(9.6 \%$, CI 95\% $=[3.2,21.0], n=5)$.

Table 3 here

Table 3 displays the frequency of reported recovered memories of childhood abuse by therapist and therapy types. The types of therapist the most associated with such reported recovered memories were Psychiatrist-psychoanalyst $(6.3 \%$, CI 95\% $=[1.3,17.2], n=3)$ and Psychologist $(6.3 \%$, CI 95\% $=[3.6,10.2], n=15)$. The least associated type was Psychologist-psychoanalyst $(3.2 \%$, CI $95 \%=[0.4,11.0], n=2)$. The type of therapy the most associated with reported recovered memories of childhood abuse was Behavioral Therapy 
$(15.0 \%$, CI $95 \%=5.7,29.8], n=6)$, while the least associated was Emotion Focused Therapy $(1.9 \%$, CI $95 \%=[0.0,10.3], n=1)$.

Table 3 here

Associated Types of Abuse. For this question, the participants had the opportunity to choose more than one response modality. The most reported type of abuse for which the participant reported recovered memories during therapy was sexual abuse $(78.8 \%$, CI $95 \%=$ $[61.1,91.0], n=26)$, followed by emotional abuse $(54.5 \%$, CI 95\% $=[36.4,71.9], n=18)$, physical abuse $(48.5 \%$, CI 95\% $=[30.8,66.4]), n=16)$, neglect $(18.2 \%$, CI 95\% $=[7.0,35.5]$, $n=6)$ and, finally, other types of abuse $(12.1 \%$, CI 95\% $=3.4,28.2], n=4)$.

Gender of Client. There was no significant difference between male, female and other gender clients reporting discussion about repressed memories with their therapist (male: $8.3 \%$, CI $95 \%=[4.7,13.4], n=15$; female: $11.7 \%$, CI 95\% $=[8.5,15.4], n=42$; other: $9.1 \%$, CI $95 \%=[0.2,41.3], n=1), \chi^{2}(4, N=551)=2.587, p=.629$, Cramer's V $=0.048$. However, we found a statistically significant difference between male, female and other genders on reporting recovered memories of childhood abuse during therapy, as male participants reported fewer cases of such memories $(2.2 \%, \mathrm{CI} 95 \%=[0.6,5.6], n=4$; female: $7.8 \%, \mathrm{CI}$ $95 \%=[8.5,15.4], n=28$; other: $9.1 \%$, CI 95\% $=[0.2,41.3], n=1), \chi^{2}(4, N=551)=6.770, p$ $=.034$, Cramer's $\mathrm{V}=0.111$, Bayes Factor ${ }_{10}=0.447\left(\mathrm{BF}_{01}=2.237\right)$.

Context of recovered memory recall. No participant reported having recovered childhood abuse memories only during a therapy session $(0.0 \%$, CI one-sided $97.5 \%=[0.0$, 10.6], while $20(60.6 \%$, CI 95\% = $[42.1,77.1])$ reported remembering the abuse outside a therapy session, and $13(39.4 \%$, CI 95\% $=[22.9,57.9]$ both inside and outside a therapy.

As for the forms of formerly forgotten abuse, participants had the opportunity to chose amongst more than one option when asked how they remembered it. The most reported context of remembering was flashbacks $(45.5 \%$, CI 95\% $=[28.1,63.6], n=15)$, followed by 
body memories $(21.2 \%$, CI 95\% $=[0.9,38.9], n=7)$, panic attacks $(15.2 \%$, CI 95\% $=[5.1$, 31.9], $n=5)$, triggered by a case history in a book $(12.1 \%$, CI $95 \%=[3.4,28.2], n=4)$, and triggered by someone else's memory of abuse during a counselling group, triggered by a movie, dream interpretation (for each: $6.1 \%$, CI 95\% $=[0.7,20.2], n=2$ ). No participant reported that the remembering occurred hypnosis or during a session of guided imagery (for both: $0.0 \%$, CI one-sided $97.5 \%=[0.0,10.6], n=0)$.

\section{Association between number of reported discussions about repressed memories}

and reported recovered memories of childhood abuse. An association between reported discussions about repressed memories and reported recovered memories of childhood abuse during therapy was found, $\chi^{2}(2, N=551)=44.46, p<.001$, Cramer's $\mathrm{V}=0.284, \mathrm{BF}_{10}=$ 131701. More precisely, of the 58 participants who reported such discussions, $13(22.4 \%$, CI $95 \%=[12.5,35.3])$ also reported recovered memories, while $45(77.6 \%$, CI 95\% $=[64.7$, 87.5]) did not. These amounts were quite similar to the ones related to the 23 participants who reported that they did not know or were not sure if they had such discussion with their therapist (did report recovered memories: $21.7 \%$, CI 95\% $=[7.5,43.7], n=5$; did not report recovered memories: $78.3 \%$, CI 95\% $=[56.3,92.5], n=18)$. By contrast, only 15 of the 470 participants $(3.2 \%$, CI $95 \%=[1.8,5.2])$ who did not report such discussions stated that they recovered memories of childhood abuse during therapy (455 of them did not, $96.8 \%$, CI 95\% $=[94.8,98.2])$.

An association between the person (e.g., therapist or client) who discussed the issue of repressed memories and the reports of recovered memories was found, $\chi^{2}(3, N=58)=8.969$, $p=.030$, Cramer's $\mathrm{V}=0.393, \mathrm{BF}_{10}=5.381$. Participants reported more recovered memories when they reported having first addressed the issue of repressed memories $(40.9 \%$, CI $95 \%=$ $[20.7,63.6], n=9)$, than when it was the therapist who first mentioned it $(4.2 \%$, CI $95 \%=$ 
$[0.1,21.1], n=1$; "I can't recall": $25 \%$, CI $95 \%=[3.2,65.1], n=2 ;$ "Other": $25 \%$, CI 95\% $=$ $[0.6,80.0], n=1)$.

Percentage of participants who cut off of contact with family and acquaintances. Seven of the 33 participants $(24.1 \%$, CI $95 \%=[10.3,43.5])$ who reported that they recovered memories of childhood abuse during therapy also reported that they became estranged from family or acquaintances (22 reported that they had not cut off of contact, $75.9 \%$, CI $95 \%=$ $[56.5,89.7])$. Of those 7 participants, $4(57.1 \%$, CI 95\% $=[18.4,90.1])$ reported they still had no contact with family or acquaintances, and $3(42.9 \%$, CI 95\% $=[9.9,81.6])$ reported that they resumed limited contact ( 0 reported that they resumed full contact, $0.0 \%$, CI one-sided $97.5 \%=[0.0,41.0])$. A large majority of participants who reported recovered memories $(N=$ 33) considered that their memories were accurate $(90.1 \%$, CI 95\% $=[75.7,98.1], n=30)$.

\section{Beliefs in repressed memory and recovered memory therapies' effectiveness. No} statistically difference was found between the believers and non-believers in repressed memory in their report of recovered memories during therapy, $\chi^{2}(2, N=551)=1.726, p=$ .422 , Cramer's $V=0.056$. Of the 551 participants who had therapy and also reported that they believed in repressed memory $(N=369), 6.8 \%(\mathrm{CI} 95 \%=[4.4,9.8], n=25)$ reported recovered memories, while this amount reached 3.2\% (CI 95\% $=[0.7,9.0], n=3)$ of the 94 participants who reported that they did not believe in repressed memory, and 5.7\% (CI 95\% = $[1.9,12.8], n=5)$ of the 88 participants who did not know whether they believed in repressed memory.

Similarly, no statistically difference was found between participants who reported continuous beliefs in repressed memories and those who reported that they had not always believed in repressed memory in their report of recovered memories during therapy, $\chi^{2}(1, N=$ $369)=0.004, p=.949$, Cramer's $V=0.003$. Of the 369 participants who believed in repressed memory, $6.7 \%(\mathrm{CI} 95 \%=[4.2,10.2], n=20)$ of those who had always believed in 
repressed memory $(N=297)$ reported recovered memories, while of the 72 participants who had not always believed in repressed memory, $6.9 \%(\mathrm{CI} 95 \%=[2.3,15.5], n=5)$ also reported recovered memories.

Finally, we found a statistically significant difference between believers in recovered memory therapies' effectiveness and non-believers in their report of recovered memory, $\chi^{2}(2$, $N=551)=11.21, p=.004$, Cramer's $\mathrm{V}=0.143, \mathrm{BF}_{10}=0.537\left(\mathrm{BF}_{01}=1.864\right)$. Of the 551 participants who had therapy and also reported that they believed in recovered memory therapies' effectiveness $(N=162), 11.1 \%(\mathrm{CI} 95 \%=[6.7,17.0], n=18)$ reported recovered memories. This amount reached $2.9 \%(\mathrm{CI} 95 \%=[0.9,6.6], n=5)$ of the 173 participants who did not believe in such therapies' effectiveness, and $4.6 \%$ (CI 95\% $=[2.2,8.3], n=5)$ of the 216 participants who did not know whether they believed in their effectiveness.

\section{Discussion}

In this study, we sought to determine the frequency with which participants in a French non-clinical sample reported having recovered memories of childhood abuse during psychotherapy. To do this, we replicated Patihis and Pendergrast's study (2019), conducted on a US sample. We also wanted to respond to one of the limitations raised by the authors by asking for clarification of what participants meant when they reported having recovered memories.

We found that about two out of five participants had received or were receiving psychotherapy. Of these, about one in ten participants reported that he/she had discussed the possibility of repressed memories with their therapist, and six percent reported that they had recovered memories of childhood abuse. Extended to the full sample, these rates reach $4.4 \%$ and $2.5 \%$, respectively. Interestingly, oldest therapies associated with discussions about repressed memories and with recovered memories took place in the 1990s (i.e., 1995-1999). In addition, although we hypothesized that therapies focusing on psychological trauma would 
be more associated with discussions on repressed memories, as well as memories recovered in therapies, than evidence-based therapies with strong theoretical background, we found that the therapies during which the most memories were recovered were behavioral, cognitivebehavioral, and EMDR therapies.

\section{Frequencies of Discussions and Recovered Memories during Therapy}

As aforementioned, the oldest therapies during which therapists and clients discussed the possibility of repressed memories, and during which memories were recovered, date back to between 1995 and 1999 . This may seem surprising given that the popularity of psychoanalysis and its associated concepts (e.g., repression) dates back to the 1970s and before. Although repression was deeply rooted in psychoanalytic theory, these therapies may not have as objective the recovery of allegedly repressed memories (e.g., modern psychodynamic therapies relying on Freudian theories; Shedler, 2010).

This period of time corresponds to the end of what scholars usually call the "memory wars'. Moreover, the highest rate of discussions about repressed memories corresponds to the period 1995-1999 (i.e., 20\% of participants who have undergone therapy). Regarding recovered memories, the rates are somewhat equivalent from 1995 to 2009 (i.e., between 8 and $8.7 \%$ of participants who had therapy), before falling until 2018 (i.e., between 4 and 5\%). In the French context, we could expect an increase from 2018 onwards. In August 2018, a law extending the statute of limitations for sexual abuse committed against children was passed and officially guided by a trauma model of dissociative amnesia (see Dodier \& Tomas, 2019). On this occasion, dissociative amnesia was widely covered in the media and French proponents were regularly invited to explain this mechanism. Nevertheless, there are other arguments for long statute of limitations that do not emphasize the trauma model of dissociative amnesia (e.g., Goldfarb, Goodman, Larson, Eisen, \& Qin, 2019). 
Although lower than those observed in the Patihis and Pendergrast study (2019), the observed rates of reports of childhood abuse memories recovered in therapies in France are not negligible, and are of interest. We were unable to conduct this study on a perfectly representative sample of the French population, and that limitation is important. Nevertheless, the size and the diversity of our sample (in terms of age and gender) raises the possibility that memories recovered in therapies could affect at least hundreds of thousands of people in France.

Before going into more detail, we would like to discuss the fact that even when we included follow-up questions, it appears that more than a half of the respondents who reported having recovered memories really did mean recovered memories of abuse for which they were not previously aware of. This is important because the general public's understanding of the concept of repressed and/or recovered memories has been challenged on several occasions to criticize published survey data (e.g. Brewin \& Andrews, 2014; Goodman, Gonzalves, \& Wolpe, 2019).

It is also worth discussing the frequencies of participants who reported reinterpreting continuous memories as childhood abuse during therapy (i.e., $5 \%$ of the participant who undergone therapy), or working on memories of abuse with their therapist (i.e., 13\%). In the first case, we can assume that such a reinterpretation can cause harm to patients, to the point of developing post-traumatic disorders (McNally \& Geraerts, 2009). In addition, and this may be the focus of future research, we may wonder to what extent the therapist has intervened, including through suggestions, to get patients to reinterpret their memories. In the second case, given the limited knowledge and false beliefs about how memory works adopted by French psychologists and psychiatrists (Dodier, 2018; Dodier \& Payoux, 2017), we can question the techniques potentially used by therapists to work on memories of childhood abuse. We saw in the introduction that some methods are recognized as possibly increasing 
false memories (e.g., guided imagery). Similarly, recent data have shown that the techniques used in EMDR — whose explicit objective is to reduce the emotional and traumatic impact of some memories (Shapiro, 2018) — can facilitate false memories of suggested information by therapists (Houben et al., 2018). Thus, although these are not strictly speaking recovered memories, such practices can still lead to memory distortions if the methods used are not precautionary (see Dodier \& Otgaar, in press, for recommendations towards clinicians in how to interview patients with a history of trauma).

\section{Therapist and Therapy Types}

It is complicated to explain why psychiatrists were most associated with discussion relationships between therapist and client, as well as with reports of recovered memories. One possibility may be that in France, the training of psychologists is probably more theoretical and includes, in the first years of study, more content on the ordinary functioning of memory (i.e., ordinary forgetting, false memories and associated theories). Psychiatrists, on the other hand, study medicine in a fairly general way for six years before specializing in psychiatry. In this case, their training is less theoretical and oriented towards the ordinary functioning of memory. Thus, psychologists may be more sceptical about repressed traumatic memories than psychiatrists. However, such a hypothesis needs to be explored deeply.

Several types of therapy were associated with discussions on repression. Interestingly and quite consistently with Patihis and Pendergrast (2019), the most associated types of therapies were both therapies whose purpose is to focus on past traumas (i.e., EMDR, Acceptance and Commitment Therapy), and therapies whose purpose is not a priori the case (i.e., Behavioral Therapy). A similar pattern was found regarding the frequency of recovered memories reported by participants (i.e., focused on trauma: EMDR; not focused on trauma: behavioral and cognitive-behavioral therapies). The fact that therapies such as EMDR lead to higher frequencies of discussion and recovered memories than the average frequency is rather 
coherent: the objective of this therapy is to manage trauma. However, such a result with behavioural and cognitive-behavioural therapies is more unexpected. This suggests that despite theoretical backgrounds that are somewhat contrary to repression theories and a therapeutic focus on symptoms rather than their cause (e.g., trauma), therapists could nevertheless integrate techniques to recover previously inaccessible memories. Despite their effectiveness in the treatment of several types of psychopathologies (David, Cristea, \& Hofmann, 2018), behavioural and cognitive-behavioural therapies have been nevertheless found to be sometimes associated with malpractices (Hipol \& Deacon, 2013; SchermulyHaupt, Linden, \& Rush, 2018). In summary, while repression has its origin in psychoanalysis, the popularity of this concept may have led to its acceptance by practitioners from other schools of thought.

Noteworthy, a substantial number of participants told us that they had followed other types of therapies, or did not know what type of therapies they had followed. If the description we asked them for helped us classify some answers in the predefined categories, others did not (e.g., "I was talking, the therapist was listening", "we worked on my issues", "basic therapy", "not psychoanalytic therapy, that's for sure"). These two categories, "other types" and "I don't know", were however associated with $8.7 \%$ of recovered memories, which is above the average frequency. Not being able to identify the therapeutic techniques used is a limitation to our results. Nevertheless, we can make two hypotheses about these response choices. This may indicate a difficulty for participants to identify the different therapies they can undertake. In this case, it suggests that those who knew how to define the type of therapy they had were probably confident. It may also indicate that therapists used methods that were not identifiable by participants: either because their approach was not clearly defined or because several approaches were used during the same therapy.

\section{Abuse Type, Gender, and Context of Recovery}


In accordance with our hypothesis, the type of abuse most common that were recovered in therapy was sexual abuse. Interestingly, sexual abuse was not the most common type of abuse in an American sample (Patihis \& Pendergrast, 2019). There is no obvious and straightforward explanation as to why such a proportion has not been found in the US. Further research should investigate the focus of recovered memory therapies to clarify such a discrepancy. Similarly, in our sample, women reported having more recovered memories than men. As we pointed out, more women are victims of sexual abuse during their childhood (Debauche et al., 2017). This could encourage therapists to both hypothesize more about repressed memories of sexual abuse and to implement more techniques to recover so-called repressed memories with woman clients.

An interesting result is that no participant who reported having recovered memories in therapy reported having only recovered them during a session. Rather, participants reported that they recovered them mostly outside a session, or to a lesser extent, both during and outside sessions. This result contrasts with those of Patihis and Pendergrast (2019) who observed that a majority of participants reported recovering memories both outside and during a session, with some participants reporting recovering memories in a therapy session. Nevertheless, the result of the current study is consistent with the answers given to the question of how they recovered these memories, since the majority referred to contexts that could be external to the therapy (e. g., flashbacks, panic attacks, triggered by a case history in a book). Surprisingly, however, no cases of hypnosis or guided imaging were reported by participants. Although hypnosis is quite popular in France, it may be more popular with patients for other issues than recovering memories of childhood abuse (e.g., quitting smoking, phobia treatment, pain relief; see, for instance, Chabridon, Nekrouf, \& Bioy, 2017).

\section{Consequences of Discussions and Recovered Memories}


We found a very strong association between discussing the possibility of repressed memories and having recovered memories of abuse in therapy. However, as Patihis and Pendergrast (2019) suggested, this is a correlational result and some parameters may be missing to suggest a causal relationship. This is why, following the authors' suggestion, we added a follow-up question to determine which of the patient or therapist had addressed the subject of repressed memories first. We found that participants reported more recovered memories of abuse in therapy when they spoke to their therapist first about repressed memories than when it was the opposite. People entering therapy because of potential psychopathology may be particularly motivated to find explanations for their mental state. As suggested in past research, these people might then be particularly suggestible (Scoboria et al., 2017). This could then explain why we found (i) it was mainly the clients who started the discussion on repression, and (ii) an association between discussion of repression and memories recovered during therapy.

Although we did not observe an association between believing in repressed memories and the frequency of memories recovered in therapy, we did observe a link between the latter and the belief in the effectiveness of recovered memory therapy, as we had assumed. It is therefore possible that techniques to recover memories may have been initiated at the request of clients, since those who have recovered memories seem to have first made this hypothesis. Again, these are first results, and further research on the causal links between therapy, beliefs about repressed memories and recovered memories is needed.

Almost $25 \%$ of participants who reported having recovered memories during therapy also reported having cut off ties with their family or acquaintances. We predicted such a consequence, but the percentage we observed was lower than that observed by Patihis and Pendergrast (2019). It should be noted that, in the current study, none of the participants who broke contact reported that they had resumed full contact. This can be related to the fact that 
about $90 \%$ of participants who have recovered memories during therapy believe that their memories are accurate. One consequence that neither Patihis and Pendergrast (2019) nor this study has explored is that of legal consequences. Future surveys may focus on the frequency of participants reporting that they have filed a complaint based on their recovered memories of past abuse.

\section{Limitations and Conclusion}

We must proceed with a caveat regarding the generalizability of our results. Contrary to Patihis and Pendergrast (2019), we were unable to conduct this study with a sample that was representative of age, for example. This was a non-clinical general public population. Thus, it was not possible for us to weight the observed frequencies to accurately extrapolate them to the entire French population. In addition, we selected our sample using the social networks Twitter and Facebook, which raises the concern whether the users of these online social networks are representative of the French public. A report conducted by the Pew Research Center (2018) highlighted that Facebook is used by all age groups up to 65 years of age, but that younger people (i.e., 18-29 years old) are more likely to use Twitter than older adults. Because the most represented age groups in our sample were the $18-29(42.1 \% ; n=$ $552)$ and the $30-49$ years old $(50.2 \% ; n=659)$, this could explain why in our sample the earliest reports of recovered memories were relatively recent (i.e., mid-1990s). As mentioned above, given the size of our sample and its diversity in terms of age and gender, we can speculate that there may be many individuals in France that recover memories of childhood abuse in therapy. To give readers an insight, $2.5 \%$ of individuals aged 18 -year and over would represent almost 1,300,000 individuals in France (i.e., in 2018, in France, 50,949,347 individuals were 18 years old or over).

We cannot rule out participants adopted a liberal response bias, leading them to easily answer "yes". However, we had included questions to control such bias as much as possible 
(i.e., as in the replicated study questionnaire, we included two consequence-free questions asking if they skimmed or misstated their age). Similarly, we cannot rule out the hypothesis that the answers given by participants — based on their memories - may have changed over time, or that a suggestion in one of our questions may have influenced their memories of their therapy. Another issue that might be explored in future research is that some participants may have gone through more than one therapy type, but only reported one of those types. Future research should therefore ask participants who have used more than one type of therapy to specify the type of therapy they recovered memories of abuse in.

Also, some issues remain unaddressed in the current study. For example, we could have asked for additional abuse-related information: was the abuse committed intra-family? Committed by relatives who are not family members? By unknown person(s)? Was the abuse repeated over time? Etc. It seems interesting to go further in the analysis of the content of recovered memories, and we encourage researchers to do so. It would be also interesting to try to estimate the proportion of memories recovered during therapy in all the different contexts in which memories of abuse are recovered. If such memories may have been suggestively recovered during therapy, and thus their reliability is questionable, this seems to be less the case when memories are spontaneously recovered following exposure to retrieval cues (e.g., by returning to the scene of the abuse, without having any memories or knowledge of it). Finally, future attempts to replicate the Patihis and Pendergrast study (2019) and our current study could try to distinguish between memories that participants were not aware of before entering therapy with those that they had just not thought about for a while. This could be achieved through the use of follow-up questions.

In conclusion, we observed percentages of (i) discussions between therapists and clients about repressed memories and (ii) memories recovered in therapies lower than those observed by Patihis and Pendergrast (2019). Although this may be due to the different 
sampling methods used, we propose an alternative, more contextual explanation. So-called 'memory wars' took place more so in the US (compared to France), and have been the scene of particularly lively exchanges between proponents and sceptics, even including death threats received by some researchers (Loftus, in press). Such debates on scientific topics can lead to polarization of opinions rather than consensus building (e.g., Hart \& Nisbet, 2012). This polarization may have resulted in some US therapists engaging in methods dedicated to recovering such memories. Another explanation may be that recovered memories are an ongoing concern in France. As we have seen, the most recent cases seem to date back to the 1990s, while in the US, some cases were observed as early as the 1970s. It therefore seems consistent to observe proportions of memories recovered during therapies that are more important in the US than in France. In any case, our results with a cumulative addition to those observed in the US will, we hope, contribute to help illuminate current therapy practices.

\section{Declaration of interest statement}

The authors report no conflict of interest. 


\section{References}

Agence France Presse. (2017, May 05). Une kiné condamnée à un an de prison avec sursis pour avoir induit de faux souvenirs [A physiotherapist sentenced to a year in prison with a suspended sentence for inducing false memories]. France TV Info. Retrieved from https://www.francetvinfo.fr/sante/affaires/une-kine-condamnee-a-un-an-de-prison-avecsursis-pour-avoir-induit-de-faux-souvenirs 2203960.html

Alexander, K. W., Quas, J. A., Goodman, G. S., Ghetti, S., Edelstein, R. S., Redlich, A. D., ... Jones, D. P. H. (2005). Traumatic impact predicts long-term memory for documented child sexual abuse. Psychological Science, 16(1), 33-40. http://doi.org/10.1111/j.0956$\underline{7976.2005 .00777 . x}$

American Psychiatric Association. (2013). Diagnostic and statistical manual of mental disorders (5th ed.). Washington, DC: American Psychiatric Publishing.

Amouroux, R. (2017). Beyond indifference and aversion: The critical reception and belated acceptance of behavior therapy in France. History of Psychology, 20(3), 313-329. http://doi.org/10.1037/hop0000064

Anderson, M. C., \& Green, C. (2001). Suppressing unwanted memories by executive control. Nature, 410, 366-369. http://doi.org/10.1038/35066572

Bass, E., \& Davis, L. (1988). The courage to heal: A guide for women survivors of child sexual abuse. New York, NY: Harper Perennial.

Beck, A. T. (2016). Cognitive therapy: Nature and relation to behavior therapy - Republished article. Behavior Therapy, 47(6), 776-784. http://doi.org/10.1016/j.beth.2016.11.003

Brand, B. L., Dalenberg, C. J., Frewen, P. A., Loewenstein, P. J., Schielke, H. J., Brams, J. S. \& Spiegel, D. (2018). Trauma-related dissociation is no fantasy: Addressing the errors of omissions and errors commission in Merckelbach and Patihis (2018). Psychological Injury \& Law, 11, 377-393. https://doi.org/10.1007/s12207-018-9336-8 
Bremner, J. D. M., Krystal, J. H., Charney, D. S., \& Southwick, S. M. (1996). Neural mechanisms in dissociative amnesia for childhood abuse. American Journal of Psychiatry, 153, 7 (Supp.), 71-82.

Brewin, C. R., \& Andrews, B. (2014). Why it is scientifically respectable to believe in repression: A response to Patihis, Ho, Tingen, Lilienfeld, and Loftus (2014). Psychological Science, 25(10), 1964-1966. https://doi.org/10.1177/0956797614541856

Brewin, C. R., \& Andrews, B. (2017). Creating memories for false autobiographical events in childhood: A systematic review. Applied Cognitive Psychology, 31(1), 2-23. http://doi.org/10.1002/acp.3220

Briere, J., \& Conte, J. (1993). Self-reported amnesia for abuse in adults molested as children. Journal of Traumatic Stress, 6(1), 21-31. http://doi.org/10.1002/jts.2490060104

Bulevich, J. B., Roediger, H. L., Balota, D. A., \& Butler, A. C. (2006). Failures to find suppression of episodic memories in the think/no-think paradigm. Memory \& Cognition, 34(8), 1569-1577. http://doi.org/10.3758/BF03195920

Calvillo, D. P., \& Emami, A. S. (in press). Do lateral eye movements increase susceptibility to misinformation? A registered replication. Psychonomic Bulletin \& Review. Advance online publication. https://doi.org/10.3758\%2Fs13423-019-01641-6

Chabridon, G., Nekrouf, N., \& Bioy, A. (2017). État des lieux des pratiques actuelles de l'hypnose au sein des centres hospitaliers universitaires français [Description of current hypnosis practice in French university hospitals]. L'Encéphale, 43(5), 498-501. http://doi.org/10.1016/j.encep.2016.06.006

Cohen, J. A., Mannarino, A. P., Kliethermes, M., \& Murray, L. A. (2012). Trauma-focused CBT for youth with complex trauma. Child Abuse \& Neglect, 36(6), 528-541. http://doi.org/10.1016/j.chiabu.2012.03.007 
Combalbert, N., Andronikof, A., Armand, M., Robin, C., \& Bazex, H. (2014). Forensic mental health assessment in France: Recommendations for quality improvement. International Journal of Law and Psychiatry, 37(6), 628-634. http://doi.org/10.1016/j.ijlp.2014.02.037

Dalenberg, C. J., Brand, B. L., Gleaves, D. H., Dorahy, M. J., Loewenstein, R. J., Cardeña, E., ... Spiegel, D. (2012). Evaluation of the evidence for the trauma and fantasy models of dissociation. Psychological Bulletin, 138(3), 550-588. https://doi.org/10.1037/a0027447

Dammeyer, M. D., Nightingale, N. N., \& McCoy, M. L. (1997). Repressed memory and other controversial origins of sexual abuse allegations: Beliefs among psychologists and clinical social workers. Child Maltreatment, 2(3), 252-263. http://doi.org/10.1177/1077559597002003007

David, D., Crista, I., \& Hofmann, S. G. (2018). Why cognitive behavioral therapy is the current gold standard of psychotherapy. Frontiers in Psychology, 9(4). http://doi.org/10.3389/fpsyt.2018.00004

Debauche, A., Lebugle, A., Brown, E., Lejbowitz, T., Mazuy, M. Charruault A., ... Hamel, C. (2017). Enquête Virage et premiers résultats sur les violences sexuelles [Virage Survey and first results on sexual violences]. Institut National d'Études Démographiques, 67 p.

Deffenbacher, K. A., Bornstein, B. H., Penrod, S. D., \& McGorty, E. K. (2004). A metaanalytic review of the effects of high stress on eyewitness memory. Law and Human Behavior, 28(6), 687-706. http://doi.org/10.1007/s10979-004-0565-x

DePrince, A. P., Brown, L. S., Cheit, R. E., Freyd, J. J., Gold, S. N., Pezdek, K., \& Quina, K. (2012). Motivated forgetting and misremembering: Perspectives from betrayal trauma theory. In R. Belli (Ed.), True and false recovered memories (pp. 193-242). New York, NY: Springer. 
Dodier, O. (2019). A bibliometric analysis of the recovered memory controversy in the $21 \mathrm{st}$ century. Applied Cognitive Psychology, 33(4), 571-584.

https://doi.org/10.1002/acp.3498

Dodier, O. (2018). The need for memory experts in French courts. Journal of Forensic Psychology Research and Practice, 18(2), 158-176. http://doi.org/10.1080/24732850.2018.1444912

Dodier, O., Melinder, A., Otgaar, H., Payoux, M., \& Magnussen, S. (in press). Psychologists and psychiatrists in court: What do they know about eyewitness memory? A comparison of experts in inquisitorial and adversarial legal systems. Journal of Police and Criminal Psychology. Advance online publication. https://doi.org/10.1007/s11896019-09339-0

Dodier, O., \& Otgaar, H. (in press). The forensic and clinical relevance of evidence-based investigative interview methods in historical sexual abuse cases. Clinical Psychological Science. https://doi.org/10.1177/2167702619858287

Dodier, O., \& Payoux, M. (2017). Connaissances et croyances des psychologues et psychiatres experts judiciaires concernant le fonctionnement de la mémoire [French psychologists and psychiatrists serving as court experts' knowledge and beliefs about memory]. L'Année Psychologique/Topics in Cognitive Psychology, 117(2), 139-171. http://doi.org/10.4074/S0003503317000483

Dodier, O., \& Tomas, F. (2019). When psychological science fails to be heard: The lack of evidence-based arguments in a ministerial report on child sexual abuse. Psychiatry, Psychology and Law, 26(3), 385-395. https://doi.org/10.1080/13218719.2018.1506716

Dodier, O., Tomas, F., Payoux, M., \& Elissalde, B. (2019). Professional experience in investigative interviewing does not guarantee strong knowledge about memory. 
Psychological Research on Urban Society, 2(1), 117-125.

http://doi.org/10.7454/proust.v2i1.49

Elliott, D. M. (1997). Traumatic events: Prevalence and delayed recall in the general population. Journal of Consulting and Clinical Psychology, 65(5), 811-820. http://doi.org/10.1037/0022-006X.65.5.811

Elliott, D. M., \& Briere, J. (1995). Posttraumatic stress associated with delayed recall of sexual abuse: a general population study. Journal of Traumatic Stress, 8(4), 629-647. http://doi.org/10.1007/BF02102892

Engelhard, I. M., McNally, R. J., \& van Schie, K. (2019). Retrieving and modifying traumatic memories: Recent research relevant to three controversies. Current Directions in Psychological Science, 28(1), 91-96. http://doi.org/10.1177/0963721418807728

Freud, S. (1893-1895/1953). The psychotherapy of hysteria. In J. Strachey (Ed. \& Trans.), The standard edition of the complete psychological works of Sigmund Freud (Vol. 2, pp. 145-174). London, UK: Hogarth.

Freud, S. (1915). Repression. In J. Strachey (Ed. \& Trans.), The standard edition of the complete psychological works of Sigmund Freud (pp. 214-243). London, UK: Hogarth.

Freud, S. (1966). The psychology of everyday life. New York, NY: W. W. Norton \& Company.

Freyd, J. (1994). Betrayal trauma: Traumatic amnesia as an adaptive response to childhood abuse. Ethics \& Behavior, 4(4), 307-329. http://doi.org/10.1207/s15327019eb0404 1

Garry, M., Manning, C. G., Loftus, E. F., \& Sherman, S. J. (1996). Imagination inflation: Imagining a childhood event inflates confidence that it occurred. Psychonomic Bulletin \& Review, 3(2), 208-214. http://doi.org/10.3758/BF03212420

Goldfarb, D., Goodman, G. S., Larson, R. P., Eisen, M. L., \& Qin, J. (2019). Long-term memory in adults exposed to childhood violence: Remembering genital contact nearly 
20 years later. Clinical Psychological Science, 7(2), 381-396.

https://doi.org/10.1177/2167702618805742

Golding, J. M., Sanchez, R. P., \& Sego, S. A. (1996). Do you believe in repressed memories? Professional Psychology: Research and Practice, 27(5), 429-437. http://doi.org/10.1037/0735-7028.27.5.429

Goodman, G. S., Ghetti, S., Quas, J. A., Edelstein, R. S., Alexander, K. W., Redlich. A. D., ... Jones, D. P. H. (2003). A prospective study of memory of child sexual abuse: New findings relevant to the repressed-memory controversy. Psychological Science, 14(2), 113-118. http://doi.org/10.1111/1467-9280.01428

Goodman, G. S., Gonzalves, L., \& Wolpe, S. (2019). False memories and true memories of childhood trauma: Balancing the risks. Clinical Psychological Science, 7(1), 29-31. http://doi.org/10.1177/2167702618797106

Guivarch, J., Piercecchi-Marti, M.-D., Glezer, D., Murdymootoo, V., Chabannes, J-M., \& Poinso, F. (2017). Is the French criminal psychiatric assessment in crisis? International Journal of Law and Psychiatry, 51, 33-41. https://doi.org/10.1016/j.ijlp.2017.01.002

Hart, P. S., \& Nisbet, E. C. (2012). Boomerang effects in science communication: How motivated reasoning and identity cues amplify opinion polarization about climate mitigation policies. Communication Research, 39(6), 701-723. http://doi.org/10.1177/0093650211416646

Hipol, L. J., \& Deacon, B. J. (2013). Dissemination of evidence-based practices for anxiety disorders in Wyoming: A survey of practicing psychotherapists. Behavior Modification, 37(2), 170-188. http://doi.org/10.1177/0145445512458794

Holden, C. (2005). French psychoflap. Science, 307(5713), 1197a. http://doi.org/10.1126/science.307.5713.1197a 
Holmes, D. S. (1990). The evidence for repression: An examination of sixty years of research. In J. L. Singer (Ed.), Repression and dissociation: Implications for personality theory, psychopathology, and health (pp. 85-102). Chicago, IL: University of Chicago Press.

Houben, S. T. L., Otgaar, H., Roelofs, J., \& Merckelbach, H. (2018). Lateral eye movements increase false memory rates. Clinical Psychological Science, 6(4), 610-616. http://doi.org/10.1177/2167702618757658

Hulbert, J. C., \& Anderson, M. C. (2018). What doesn't kill you makes you stronger: Psychological trauma and its relationship to enhanced memory control. Journal of Experimental Psychology: General, 147(12), 1931-1949. http://doi.org/10.1037/xge0000461

Lanius, R. A., Brand, B., Vermetten, E., Frewen, P. A., \& Spiegel, D. (2012). The dissociative subtype of posttraumatic stress disorder: Rationale, clinical and neurobiological evidence, and implications. Depression \& Anxiety, 29(8), 701-708. https://doi.org/10.1002/da.21889

Laurence, J.-R., \& Perry, C. (1983). Hypnotically created memory among highly hypnotizable subjects. Science, 222(4623), 523-525. http://doi.org/10.1126/science.6623094

Lilienfeld, S. O. (2007). Psychological treatments that cause harm. Perspectives on Psychological Science, 2(1), 53-70. http://doi.org/10.1111/j.1745-6916.2007.00029.x

Loftus, E. F. (1993). The reality of repressed memories. American Psychologist, 48(5), 518537. http://doi.org/10.1037/0003-066X.48.5.518

Loftus, E. F., Garry, M., \& Feldman, J. (1994). Forgetting sexual trauma: What does it mean when 38\% forget? Journal of Consulting and Clinical Psychology, 62(6), 1177-1181. http://doi.org/10.1037/0022-006X.62.6.1177 
Loftus, E. F. (1997). Repressed memory accusations: Devastated families and devastated patients. Applied Cognitive Psychology, 11(1), 25-30. https://doi.org/10.1002/(SICI)1099-0720(199702)11:1<25::AID-ACP452>3.0.CO;2-J

Loftus, E. F. (2005). Planting misinformation in the human mind: A 30-year investigation of the malleability of memory. Learning \& Memory, 12, 361-366. http://doi.org/10.1101/lm.94705

Loftus, E. F. (in press). Eyewitness testimony. Applied Cognitive Psychology. Advance online publication. http://doi.org/10.1002/acp.3542

Loftus, E. F., Joslyn, S., \& Polage, D. (1998). Repression: A mistaken impression? Development and Psychopathology, 10(4), 781-792.

Loftus, E. F., \& Palmer, J. C. (1974). Reconstruction of automobile destruction: An example of the interaction between language and memory. Journal of Verbal Learning and Verbal Behavior, 13(5), 585-589. http://doi.org/10.1016/S0022-5371(74)80011-3

Loftus, E. F., \& Pickrell, J. E. (1995). The formation of false memories. Psychiatric Annals, 25(12), 720-725. http://doi.org/10.3928/0048-5713-19951201-07

Lynn, S. J., Evans, M., Laurence, J.-R., \& Lilienfeld, S. O. (2015). What do people believe about memory? Implications for the science and pseudoscience of clinical practice. Canadian Journal of Psychology, 60(12), 541-547. https://doi.org/10.1177/070674371506001204

Lynn, S. J., Lilienfeld, S. O., Merckelbach, H., Giesbrecht, T., McNally, R. J., ... Malaktaris, A. (2014). The trauma model of dissociation: Inconvenient truths and stubborn fictions. Comment on Dalenberg et al. (2012). Psychological Bulletin, 140(3), 896-910. http://doi.org/10.1037/a0035570

Lynn, S. J., Lock, T., Loftus, E. F., Krackow, E., \& Lilienfeld, S. O. (2003). The remembrance of things past: Problematic memory recovery techniques in 
psychotherapy. In S. O. Lilienfeld, S. J. Lynn, \& J. M. Lohr (Eds.), Science and pseudoscience in clinical psychology (pp. 205-239). New York, NY, US: Guilford Press.

Lynn, S. J., Maxwell, R., Merckelbach, H., Lilienfeld, S. O., van Heuften-van der Kloet, D., \& Miskovic, V. (in press). Dissociation and its disorders: Competing models, future directions, and a way forward. Clinical Psychology Review. Online advance publication. https://doi.org/10.1016/j.cpr.2019.101755

Melinder, A., \& Magnussen, S. (2015). Psychologists and psychiatrists serving as expert witnesses in court: What do they know about eyewitness memory? Psychology, Crime \& Law, 21(1), 53-61. http://doi.org/10.1080/1068316X.2014.915324

Mazzoni, G. A. L., Loftus, E. F., Seitz, A., \& Lynn, S. J. (1999). Changing beliefs and memories through dream interpretation. Applied Cognitive Psychology, 13(2), 125-144. http://doi.org/10.1002/(SICI)1099-0720(199904)13:2<125::AID-ACP560>3.0.CO;2-5

McNally, R. J., \& Geraerts, E. (2009). A new solution to the recovered memory debate. Perspectives on Psychological Science, 4(2), 126-134. http://doi.org/10.1111/j.1745$\underline{6924.2009 .01112 . x}$

Merckelbach, H., \& Patihis, L. (2018). Why trauma-related dissociation is a misnomer in courts: A critical analysis of Brand et al. (2017a, b). Psychological Injury and Law, 11(4), 370-376. http://doi.org/10.1007/s12207-018-9328-8

Nash, R. A., Wade, K. A., Garry, M., Loftus, E. F., \& Ost, J. (2017). Misrepresentations and flawed logic about the prevalence of false memories. Applied Cognitive Psychology, 31(1), 31-33. http://doi.org/10.1002/acp.3265

Ost, J., Easton, S., Hope, L., French, C. C., \& Wright, D. B. (2017). Latent variables underlying the memory beliefs of Chartered Clinical Psychologists, Hypnotherapists 
and undergraduate students. Memory, 25(1), 57-68.

http://doi.org/10.1080/09658211.2015.1125927

Otgaar, H., Howe, M. L., Patihis, L., Merckelbach, H., Lynn. S. J., Lilienfeld, S. O., \& Loftus, E. F. (in press). The return of the repressed: The persistent and problematic claims of long-forgotten trauma. Perspectives on Psychological Science.

Otgaar, H., Merckelbach, H., Jelicic, M., \& Smeets, T. (2017). The potential for false memories is bigger than what Brewin and Andrews suggest. Applied Cognitive Psychology, 31(1), 24-25. http://doi.org/10.1002/acp.3262

Otgaar, H., Muris, P., Howe, M. L., \& Merckelbach, H. (2017). What drives false memories in psychopathology? A case for associative activation. Clinical Psychological Science, 5(6), 1048-1069. http://doi.org/10.1177/2167702617724424

Patihis, L., Ho*, L. Y., Loftus, E. F., \& Herrera*, M. E. (in press). Memory experts' beliefs about repressed memory. Memory. Advance online publication. http://doi.org/10.1080/09658211.2018.1532521

Patihis, L., Ho, L. Y., Tingen, I. W., Lilienfeld, S. O., \& Loftus, E. F. (2014). Are the "memory wars" over? A scientist-practitioner gap in beliefs about repressed memory. Psychological Science, 25(2), 519-530. http://doi.org/10.1177/0956797613510718

Patihis, L., Otgaar, H., Merckelbach, H. (in press). Expert witnesses, dissociative amnesia, and extraordinary remembering: Response to Brand et al. Psychological Injury \& Law. Advance online publication. https://doi.org/10.1007/s12207-019-09348-8

Patihis, L., \& Pendergrast, M. H. (2019). Reports of recovered memories of abuse in therapy in a large age-representative U.S. national sample: Therapy type and decade comparisons. Clinical Psychological Science, 7(1), 3-21.

http://doi.org/10.1177/2167702618773315 
Patihis, L., \& Place, P. J. (2018). Weak evidence for increased motivated forgetting of trauma-related words in dissociated or traumatized individuals in a directed forgetting experiment. Memory, 26(5), 619-633. http://doi.org/10.1080/09658211.2017.1387666

Patihis, L., \& Younes Burton, H. J. (2015). False Memories in Therapy and Hypnosis Before 1980. Psychology of Consciousness: Theory, Research, and Practice, 2(2), 153-169. http://dx.doi.org/10.1037/cns0000044

Pennebaker, J. W. (1997). Writing about emotional experiences as a therapeutic process. Psychological Science, 8(3), 162-166. http://doi.org/10.1111/j.1467$\underline{9280.1997 . t b 00403 . x}$

Pew Research Center. (2018, March). Social Media Use in 2018. This report can be retrieved at https://www.pewinternet.org/2018/03/01/social-media-use-in-2018/

Pezdek, K., Blandon-Gitlin, I., \& Gabbay, P. (2006). Imagination and memory: Does imagining implausible events lead to false autobiographical memories? Psychonomic Bulletin \& Review, 13(5), 764-769. https://doi.org/10.3758/BF03193994

Salmona, M. (2018). Le livre noir des violences sexuelles [The black book of sexual violence]. Paris: Dunod.

Shachschal, J., Woodward, E., Wichelmann, J. M., Haag, K., \& Ehlers, A. (in press). Differential effects of poor recall and memory disjointedness on trauma symptoms. Clinical Psychological Science. Advance online publication. http://doi.org/10.1177/2167702619847195

Schermuly-Haupt, M.-L., Linden, M. R., \& Rush, A. J. (2018). Unwanted events and side effects in cognitive behavior therapy. Cognitive Therapy and Research, 42(3), 219-229. http://doi.org/10.1007/s10608-018-9904-y

Scoboria, A., Wade, K. A., Lindsay, D. S., Azad, T., Strange, D., Ost, J., \& Hyman, I. E. (2017). A mega-analysis of memory reports from eight peer-reviewed false memory 
implantation studies. Memory, 25(2), 146-163.

http://doi.org/10.1080/09658211.2016.1260747

Shapiro, F. (2018). Eye movement desensitization and reprocessing (EMDR) therapy: Basic principles, protocols, and procedures ( $3^{\text {rd }}$ Ed.). New York, NY: Guilford Press.

Shaw, J. (2018). How can researchers tell whether someone has a false memory? Coding strategies in autobiographical false-memory research: A reply to Wade, Garry, and Pezdek (2018). Psychological Science, 29(3), 477-480.

http://doi.org/10.1177/0956797617703667

Shaw, J., \& Porter, S. (2015). Constructing rich false memories of committing crime.

Psychological Science, 26(3), 291-301. http://doi.org/10.1177/0956797614562862

Shaw, J., \& Vredeveldt, A. (2018). The recovered memory debate continues in Europe:

Evidence from the United Kingdom, the Netherlands, France, and Germany. Clinical Psychological Science, 7(1), 27-28. https://doi.org/10.1177/2167702618803649

Shedler, J. (2010). The efficacy of psychodynamic psychotherapy. American Psychologist, 65(2), 98-109. http://doi.org/10.1037/a0018378

van Schie, K., \& Leer, A. (in press). Lateral eye movements do not increase false-memory rates: A failed direct-replication study. Clinical Psychological Science. Advance online publication. https://doi.org/10.1177/2167702619859335

Shields, G. S., Sazma, M. A., McCullough, A. M., Yonelinas, A. P. (2017). The effects of acute stress on episodic memory: A meta-analysis and integrative review. Psychological Bulletin, 143(6), 636-675. http://doi.org/10.1037/bul0000100

Stramaccia, D. F., Rischer, K. M., Fawcett, J., \& Benoit, R. G. (submitted). Memory suppression and its deficiency in psychological disorders: A focused meta-analysis. https://doi.org/10.31234/osf.io/5wynm 
Wade, K. A., Garry, M., \& Pezdek, K. (2018). Deconstructing rich false memories of committing crime: Commentary on Shaw and Porter (2015). Psychological Science, 29(3), 471-476. http://doi.org/0956797617703667.

Wang, Y., Luppi, A., Fawcett, J., \& Anderson, M. C. (2019). Reconsidering unconscious persistence: Suppressing unwanted memories reduces their indirect expression in later thoughts. Cognition, 187, 78-94. http://doi.org/10.1016/j.cognition.2019.02.016

Williams, L. M. (1994). Recall of childhood trauma: A prospective study of women's memories of child sexual abuse. Journal of Consulting and Clinical Psychology, 62(6), 1167-1176. http://doi.org/10.1037/0022-006X.62.6.1167

Yapko, M. D. (1994). Suggestibility and repressed memories of abuse: A survey of psychotherapists' beliefs. American Journal of Clinical Hypnosis, 36(3), 163-171. 
Table 1

Frequency of therapists and therapy types (between 1970 and 2018)

\begin{tabular}{|c|c|c|c|}
\hline & $n$ & $\%$ & CI 95\% \\
\hline \multicolumn{4}{|l|}{ Therapist type $(N=551)$} \\
\hline Psychologist & 237 & 43.0 & {$[38.8,47.3]$} \\
\hline Psychiatrist & 131 & 23.8 & {$[20.3,27.6]$} \\
\hline Psychologist-Psychoanalyst & 63 & 11.4 & {$[8.9,14.4]$} \\
\hline Psychiatrist-Psychoanalyst & 48 & 8.7 & {$[6.5,11.4]$} \\
\hline Psychoanalyst & 23 & 4.2 & {$[2.7,6.2]$} \\
\hline Coach & 1 & 0.2 & {$[0.0,1.0]$} \\
\hline Other & 48 & 8.7 & {$[6.5,11.4]$} \\
\hline \multicolumn{4}{|l|}{ Therapy type $(N=550)$} \\
\hline Psychoanalytical or psychodynamic & 123 & 22.3 & {$[18.9,26.1]$} \\
\hline Cognitive-Behavioral Therapy or Cognitive Therapy & 85 & 15.4 & {$[12.5,18.8]$} \\
\hline Emotion Focused Therapy & 52 & 9.4 & {$[7.1,12.2]$} \\
\hline Behavioral Therapy & 40 & 7.3 & {$[5.2,9.8]$} \\
\hline EMDR & 29 & 5.3 & {$[3.6,7.5]$} \\
\hline Internal Family System & 16 & 2.9 & {$[1.7,4.7]$} \\
\hline Acceptance and Commitment Therapy & 14 & 2.5 & {$[1.4,4.2]$} \\
\hline Emotional Freedom Techniques & 9 & 1.6 & {$[0.8,3.1]$} \\
\hline Hypnosis & 7 & 1.3 & {$[0.5,2.6]$} \\
\hline Gestalt-therapy & 7 & 1.3 & {$[0.5,2.6]$} \\
\hline Marriage Counselling & 5 & 0.9 & {$[0.3,2.1]$} \\
\hline Attachment-based therapy & 4 & 0.7 & {$[0.2,1.9]$} \\
\hline Attachment Therapy & 3 & 0.5 & {$[0.1,1.6]$} \\
\hline Feminist Therapy & 2 & 0.4 & {$[0.0,1.3]$} \\
\hline Survivors group & 2 & 0.4 & {$[0.0,1.3]$} \\
\hline Rebirthing-Breathwork & 2 & 0.4 & {$[0.0,1.3]$} \\
\hline Scientology auditing & 1 & 0.2 & {$[0.0,1.0]$} \\
\hline Sexual Identity Therapy & 1 & 0.2 & {$[0.0,1.0]$} \\
\hline Thought Field Therapy & 1 & 0.2 & {$[0.0,1.0]$} \\
\hline Other & 24 & 4.4 & {$[2.8,6.4]$} \\
\hline I don't know & 123 & 22.3 & {$[18.9,26.1]$} \\
\hline
\end{tabular}

Note: order of therapists and therapies is shown in descending order of "yes" percentage. 
Table 2

Identification of false positives and negatives

\begin{tabular}{|c|c|c|}
\hline Initial answer $(N=551)$ & Answer given to follow-up questions & Outcome \\
\hline \multicolumn{3}{|l|}{ No $(N=497)$} \\
\hline$n=9$ & $\begin{array}{l}\text { I wish to change my previous answer: I did not know I } \\
\text { was abused before I entered therapy, and had no } \\
\text { memory of any abuse, and the memories emerged in } \\
\text { therapy }\end{array}$ & False negative \\
\hline$n=1$ & $\begin{array}{c}\text { Even if I have recovered memories of abuse in therapy, } \\
\text { I choose not to discuss it here }\end{array}$ & \\
\hline$n=11$ & $\begin{array}{l}\text { I wish to qualify my answer: I did not know I was } \\
\text { abused before I entered therapy, but I did have memory } \\
\text { of what had happened to me, and in therapy I } \\
\text { reappraised what happened to me as abuse }\end{array}$ & True negative \\
\hline$n=59$ & $\begin{array}{l}\text { I wish to qualify my answer: I knew I was abused } \\
\text { before I entered therapy, and had memory of that abuse } \\
\text { before therapy, and I just worked on those memories in } \\
\text { therapy }\end{array}$ & True negative \\
\hline$n=417$ & $\begin{array}{l}\text { I confirm my previous answer: I have never recovered } \\
\text { memories of abuse in therapy that I previously had no } \\
\text { memory of before therapy }\end{array}$ & True negative \\
\hline \multicolumn{3}{|l|}{ Yes $(N=30)$} \\
\hline$n=17$ & $\begin{array}{l}\text { I did not know I was abused before I entered therapy, } \\
\text { and had no memory of any abuse, and the memories } \\
\text { emerged in therapy }\end{array}$ & True positive \\
\hline$n=8$ & $\begin{array}{c}\text { I did not know I was abused before I entered therapy, } \\
\text { but I did have memory of what had happened to me, } \\
\text { and in therapy I reappraised what happened to me as } \\
\text { abuse }\end{array}$ & False positive \\
\hline$n=5$ & $\begin{array}{l}\text { I knew I was abused before I entered therapy, and had } \\
\text { memory of that abuse before therapy, and I just worked } \\
\text { on those memories in therapy }\end{array}$ & False positive \\
\hline \multicolumn{3}{|c|}{ I don't know/am not sure $(N=24)$} \\
\hline$n=7$ & $\begin{array}{c}\text { I did not know I was abused before I entered therapy, } \\
\text { and had no memory of any abuse, and the memories } \\
\text { emerged in therapy }\end{array}$ & \\
\hline$n=8$ & $\begin{array}{c}\text { I did not know I was abused before I entered therapy, } \\
\text { but I did have memory of what had happened to me, } \\
\text { and in therapy I reappraised what happened to me as } \\
\text { abuse }\end{array}$ & \\
\hline$n=7$ & $\begin{array}{l}\text { I knew I was abused before I entered therapy, and had } \\
\text { memory of that abuse before therapy, and I just worked } \\
\text { on those memories in therapy }\end{array}$ & \\
\hline$n=2$ & $\begin{array}{l}\text { I have never recovered memories of abuse in therapy } \\
\text { that I previously had no memory of before therapy }\end{array}$ & \\
\hline
\end{tabular}


Table 3

By therapist and therapy types: Frequency of reported discussions about repressed memories during therapy

\begin{tabular}{|c|c|c|c|c|}
\hline & \multicolumn{3}{|c|}{$\begin{array}{l}\text { During the course of counselling or therapy, did your therapist ever discuss } \\
\text { the possibility that you might have been abused as a child but had } \\
\text { repressed the memories? }\end{array}$} & \multirow[b]{2}{*}{ Row total } \\
\hline & Yes & No & Don't know & \\
\hline \multicolumn{5}{|l|}{ Therapist } \\
\hline Psychiatrist-Psychoanalyst & $7(14.6 \%[6.1,27.8])$ & $40(83.3 \%[69.8,92.5])$ & $1(2.1 \%[0.1,11.1])$ & 48 \\
\hline Psychiatrist & $17(13 \%[7.7,20.0])$ & $110(84.0 \%[7.65,8.98])$ & $4(3.1 \%[0.8,7.6])$ & 131 \\
\hline Psychoanalyst & $2(8.7 \%[1.1,28.0])$ & $20(87.0 \%[66.4,97.2])$ & $1(4.3 \%[0.1,21.9])$ & 23 \\
\hline Psychologist & $20(8.4 \%[5.2,12.7])$ & $204(86.1 \%[81.0,90.2])$ & $13(5.5 \%[3.0,9.2])$ & 237 \\
\hline Psychologist-Psychoanalyst & $4(6.3 \%[1.8,15.5])$ & $59(93.7 \%[84.5,98.2])$ & $0(0.0 \%[0.0,5.7])^{\mathrm{a}}$ & 63 \\
\hline Other & $8(16.7 \%[7.5,30.2])$ & $36(75.0 \%[60.4,86.4])$ & $4(8.3 \%[2.3,20.0])$ & 48 \\
\hline Colum total & $58(10.5 \%[8.1,13.4])$ & $470(85.3 \%[82.1,88.2])$ & $23(4.2 \%[2.7,6.2])$ & 551 \\
\hline \multicolumn{5}{|l|}{ Therapy } \\
\hline Behavioral Therapy & $9(22.5 \%[10.8,38.5])$ & $28(70.0 \%[53.5,83.4])$ & $3(7.5 \%[1.6,20.4])$ & 40 \\
\hline Acceptance and Commitment Therapy & $3(21.4 \%[0.2,33.9])$ & $10(71.4 \%[41.9,91.6])$ & $1(7.1 \%[4.7,50.8])$ & 14 \\
\hline EMDR & $6(20.7 \%[8.0,39.7])$ & $22(75.9 \%[56.5,89.7])$ & $1(3.4 \%[0.1,17.8])$ & 29 \\
\hline Cognitive-Behavioral Therapy or Cognitive Therapy & $9(10.6 \%[5.0,19.2])$ & $74(87.1 \%[78.0,93.4])$ & $2(2.4 \%[0.3,8.2])$ & 85 \\
\hline Psychoanalytical or psychodynamic & $13(10.6 \%[5.7,17.4])$ & $109(88.6 \%[81.6,93.6])$ & $1(0.8 \%[0.0,4.4]$ & 123 \\
\hline Emotion Focused Therapy & $5(9.6 \%[3.2,21.0])$ & $45(86.5 \%[74.2,94.4]$ & $2(3.8 \%[0.5,13.2])$ & 52 \\
\hline Other & $2(8.3 \%[15.6,55.3])$ & $21(87.5 \%[67.6,97.3])$ & $1(4.2 \%[0.1,21.1])$ & 24 \\
\hline I don't know & $5(4.1 \%[1.3,9.2])$ & $111(90.2 \%[83.6,94.9])$ & $7(5.7 \%[2.3,11.4])$ & 123 \\
\hline Colum total & $58(10.5 \%[8.1,13.4])$ & $470(85.5 \%[82.2,88.3])$ & $22(4.0 \%[2.5,6.0])$ & 550 \\
\hline
\end{tabular}

Note: Percentages in parentheses are row percentages, and square brackets contain $95 \%$ CI estimates. Order of therapists and therapies is shown in descending order of "yes" percentage". aindicates CI one-sided 97.5\%. Only therapist and therapy types with $>9$ observations in total and with at least one "yes" answer are presented in this table. 
Table 4

By therapist and therapy types: Frequency of reported recovered memories during therapy (excluding false positives and including false negatives)

\begin{tabular}{|c|c|c|c|}
\hline & \multicolumn{2}{|c|}{$\begin{array}{c}\text { During the course of therapy, did you come to remember being abused as } \\
\text { a child, when you had no previous memory of such abuse? (excluding } \\
\text { false positives and including false negatives) }\end{array}$} & \multirow[b]{2}{*}{ Row total } \\
\hline & Yes & No & \\
\hline \multicolumn{4}{|l|}{ Therapist } \\
\hline Psychiatrist-Psychoanalyst & $3(6.3 \%[1.3,17.2])$ & $45(93.8 \%[82.8,98.7])$ & 48 \\
\hline Psychologist & $15(6.3 \%[3.6,10.2])$ & $222(93.7 \%[89.8,96.4])$ & 237 \\
\hline Psychiatrist & $7(5.3 \%[2.2,10.7])$ & $124(94.7 \%[89.3,97.8])$ & 131 \\
\hline Psychologist-Psychoanalyst & $2(3.2 \%[0.4,11.0])$ & $61(96.8 \%[89.0,99.6])$ & 63 \\
\hline Other & $6(12.5 \%[4.7,25.2])$ & $41(87.5 \%[74.8,95.3])$ & 48 \\
\hline Colum total & $33(6.0 \%[4.2,8.3])$ & $518(94.0[91,7,95.8])$ & 551 \\
\hline \multicolumn{4}{|l|}{ Therapy } \\
\hline Behavioral Therapy & $6(15.0 \%[5.7,29.8])$ & $34(85.0[70.2,94.3])$ & 40 \\
\hline Cognitive-Behavioral Therapy or Cognitive Therapy & $6(7.1 \%[2.6,14.7])$ & $79(92.9 \%[85.3,97.4])$ & 85 \\
\hline EMDR & $2(6.9 \%[0.8,22.8]$ & $27(93.1 \%[77.2,99.2]$ & 29 \\
\hline Psychoanalytical or psychodynamic & $4(3.3 \%[0.9,8.1])$ & $199(96.7[91.9,99.1])$ & 123 \\
\hline Emotion Focused Therapy & $1(1.9 \%[0.0,10.3])$ & $51(98.1 \%[89.7,100.0])$ & 52 \\
\hline Other & $3(12.5 \%[2.7,32.4])$ & $21(87.5 \%[67.6,97.3])$ & 24 \\
\hline I don't know & $10(8.1 \%[4.0,14.4])$ & $113(91.9 \%[85.6,96.0])$ & 123 \\
\hline Colum total & $33(6.0 \%[4.2,8.3])$ & $517(94.0[91.7,95.8])$ & 550 \\
\hline
\end{tabular}

Note: Percentages in parentheses are row percentages, and square brackets contain $95 \%$ CI estimates. Order of therapists and therapies is shown in descending order of "yes" percentage". Only therapist and therapy types with $>9$ observations in total and with at least one "yes" answer are presented in this table. 


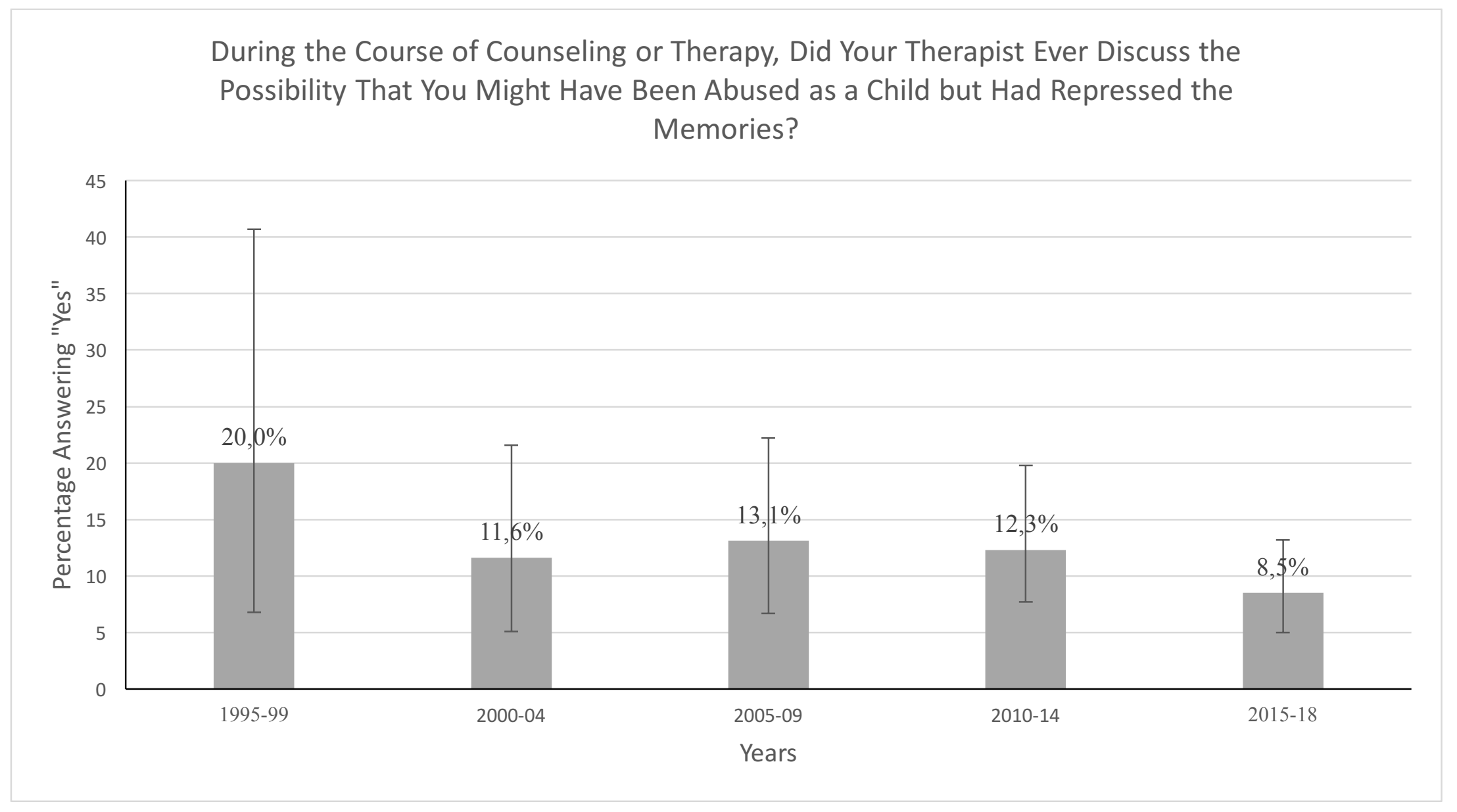

Figure 1. The proportion of participants who began therapy in a given half-decade who discussed with their therapist the possibility that they might have repressed memories. Error bars represent $95 \%$ CIs for sample proportions. 


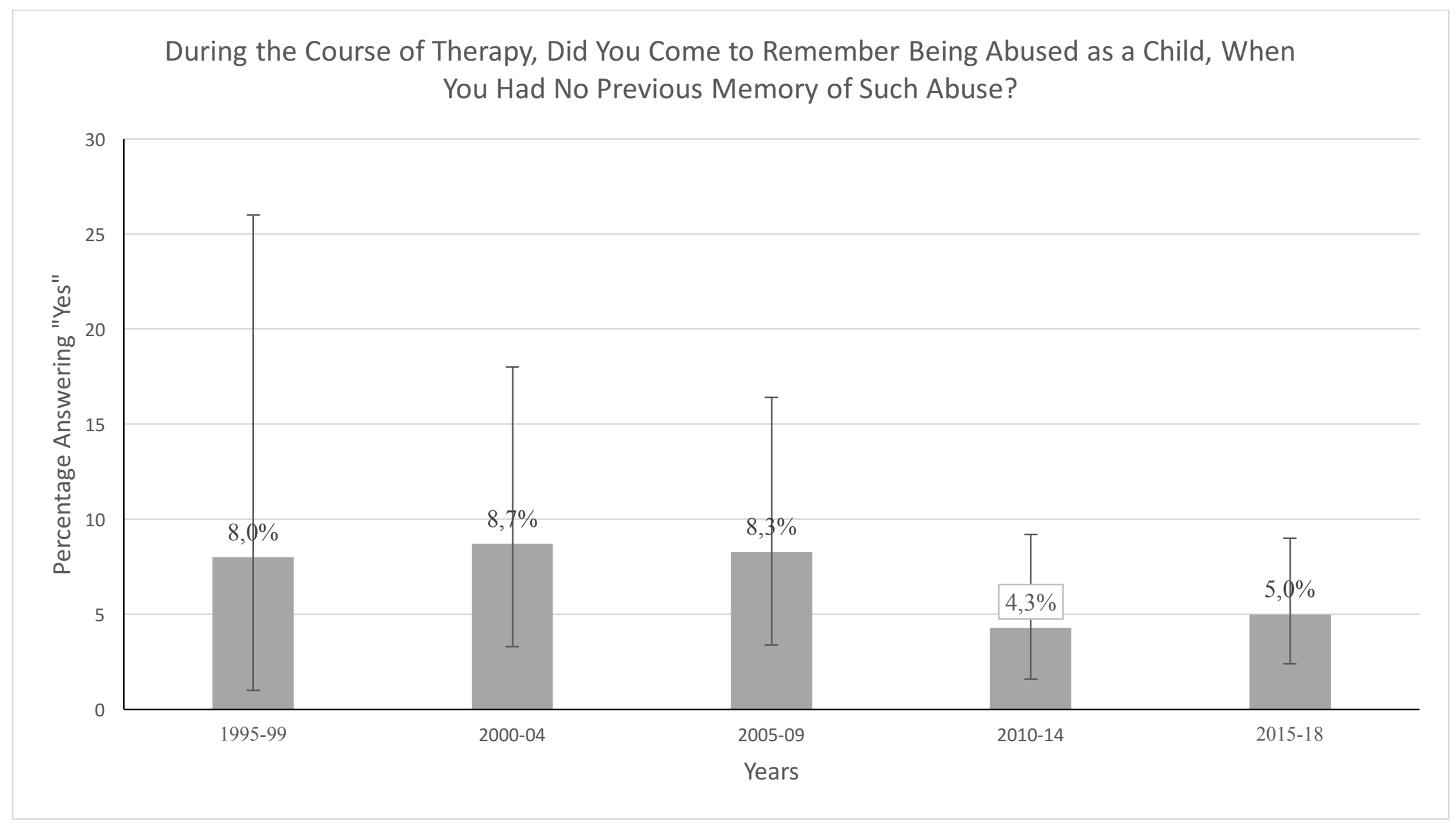

Figure 2. The proportion of participants who commenced therapy in a given half-decade who came to recover memories of childhood abuse in therapy (excluding false positives and including false negatives). The percentages of participants answering «Yes » represent the percentages after excluding false positives and including false negatives. Error bars represent $95 \%$ CIs. 


\section{Supplemental Appendix 1}

\section{Recruiting material on social media (Twitter)}

"Our research team is currently conducting a study on psychotherapies that needs you to complete this questionnaire (it takes a maximum of 20 minutes).

Thank you for sharing by retweeting!"

\section{Recruiting material on social media (Facebook)}

"Our research team is currently conducting a study on psychotherapies that needs you to complete this questionnaire (it takes a maximum of 20 minutes).

Thank you for sharing!” 


\section{Supplemental Appendix 2}

\section{Introductory note}

"We would like to ask you a few questions about the subject of psychotherapy. The information collected will allow us to better understand the influence of particular types of psychotherapy and therapeutic counselling on family relationships. However, we are aware that these are sensitive issues. Some people may feel uncomfortable with these issues. Therefore, it is important for you to know that your answers are and will remain completely anonymous and confidential. The data collected will be analyzed to produce overall averages, percentages and trends.

The first question is related to psychotherapy in general." 


\section{Supplemental Appendix 3}

\section{Central questions of the questionnaire}

1. Have you ever received counselling or psychotherapy?

- Yes

- No

- Don't know/Not sure

[If Yes was not chosen, the questions 1a through 8 below were skipped]

1a. What year did you start counselling or therapy?

1b. What type of therapy was it?

- Acceptance and Commitment Therapy (ACT) or related therapies

- Attachment Therapy

- Attachment-based therapy

- Behavioral Therapy

- Cognitive Behavioral Therapy or Cognitive Therapy

- Exposure Therapy

- Emotion Focused Therapy

- Emotional Freedom Techniques

- Eye movement desensitization and reprocessing (EMDR)

- Feminist therapy

- Hypnosis

- Internal Family Systems

- Marriage Counselling

- Neurolinguistic Programing 
- Primal Therapy or Primal Integration

- Psychodynamic or psychoanalysis

- Gestalt therapy

- Rebirthing-breathwork

- Scientology auditing

- Sexual Identity Therapy

- Survivors Group

- Thought Field Therapy

- Twelve-step program

- I don't know (please elaborate)

- Other (please specify)

2. During the course of counselling or therapy, did your therapist ever discuss the possibility that you might have been abused as a child but had repressed the memories?

- Yes

- No

- Don't know/Not sure

[If Yes was not selected on question 2., questions 2a was skipped]

2.a. Could you specify who brought up the subject of repressed memories first in therapy: Was it you or your therapist?

- My therapist brought up the subject of repressed memories first

- I brought up the subject of repressed memories first 
- I can't remember who brought it up first

3. During the course of therapy, did you come to remember being abused as a child, when you had no previous memory of such abuse?

- Yes

- No

- Don't know/not sure

[If Yes was not selected on question 3, questions 3a through 8 were skipped]

3a.1. You answered "yes": What do you mean exactly?

- I did not know I was abused before I entered therapy, and had no memory of any abuse, and the memories emerged in therapy

- I knew I was abused before I entered therapy, but had no memory of the abuse before therapy, and the memories emerged in therapy

- I did not know I was abused before I entered therapy, but I did have memory of what had happened to me, and in therapy I reappraised what happened to me as abuse

- I knew I was abused before I entered therapy, and had memory of that abuse before therapy, and I just worked on those memories in therapy

3a.2. You indicated "not sure": What do you mean exactly?

- I have never recovered memories of abuse in therapy that I previously had no memory of before therapy

- I did not know I was abused before I entered therapy, and had no memory of any abuse, and the memories emerged in therapy 
- I knew I was abused before I entered therapy, but had no memory of the abuse before therapy, and the memories emerged in therapy

- I did not know I was abused before I entered therapy, but I did have memory of what had happened to me, and in therapy I reappraised what happened to me as abuse

- I knew I was abused before I entered therapy, and had memory of that abuse before therapy, and I just worked on those memories in therapy

3a.3. You answered "no": What do you mean exactly?

- I confirm my previous answer: I have never recovered memories of abuse in therapy that I previously had no memory of before therapy

- Even if I have recovered memories of abuse in therapy, I choose not to discuss it here

- I wish to change my previous answer: I did not know I was abused before I entered therapy, and had no memory of any abuse, and the memories emerged in therapy

- I wish to qualify my answer: I knew I was abused before I entered therapy, but had no memory of the abuse before therapy, and the memories emerged in therapy

- I wish to qualify my answer: I did not know I was abused before I entered therapy, but I did have memory of what had happened to me, and in therapy I reappraised what happened to me as abuse

- I wish to qualify my answer: I knew I was abused before I entered therapy, and had memory of that abuse before therapy, and I just worked on those memories in therapy [If in any case participants did not report having recovered memories during therapy on question 3a.1, 3a.2 or 3a.2, questions 3 b through 8 were skipped]

3b. What form of abuse was it? (choose all that apply that were recovered, regardless of whether you believe the memories to be true now) 
- Sexual

- Physical

- Emotional

- Neglect

- Satanic Ritual Abuse

- Other (please specify)

3c. At what age did you come to believe the abuse started? \{i.e. age at which the alleged abuse started, not your age at the time of the memory recovery)

3d. How many years did you come to believe the abuse continued for? \{i.e. how many years did the alleged abuse last)

3e. What was the gender of the therapist?

- Male

- Female

3g. Did you remember the abuse during a therapy session or outside of a therapy session?

- Inside a Therapy Session

- Outside of a therapy Session

- Both inside and outside of a therapy session

4. Did you come to believe that you suffered from multiple personality disorder? (or dissociative identity disorder) 
- Yes

- No

5. In what year did you first remember the formerly repressed or dissociated memories of abuse? (to be clear: this means what year did you first recover the memory--NOT when the abuse started originally)

6. How did you come to remember the formerly forgotten abuse? I will list a number of possibilities. Please choose any that apply. There might be several positive responses.

- Hypnosis

- Guided Imagery

- Dream Interpretation

- Panic Attacks

- Flashbacks

- Body Memories

- Seeing a movie

- $\quad$ Triggered by someone else's memory or case history in a book

- Triggered by someone else's memory in a survivor or counselling group

- $\quad$ Other please specify

6a. Do you still believe that your recovered memories of abuse are accurate?

- Yes

- No

7. Did you cut off contact with any family members as a result of your new memories? 
- Yes

- No

[If yes was not selected on question 7. Question 8 was skipped]

8. Have you now resumed contact with these family members? Yes, full contact

- Yes

- limited contact

- No 


\section{Supplemental Appendix 4}

Reasons why 180 participants were excluded

\begin{tabular}{lccc}
\hline & $n$ & $\begin{array}{c}\text { \% of the } 180 \text { excluded } \\
\text { participant }\end{array}$ & $\begin{array}{c}\% \text { of the initial } \\
\text { total sample }\end{array}$ \\
\hline $\begin{array}{l}\text { Incomplete data relevant to our } \\
\text { analyses }\end{array}$ & 151 & 83.9 & 10.1 \\
$\begin{array}{l}\text { Inconsistency on age report (age } \\
\text { reported vs. birth date) }\end{array}$ & 13 & 7.2 & 0.9 \\
$\begin{array}{l}\text { Suspected response bias } \\
\text { Total }\end{array}$ & 16 & 8.9 & 1.1 \\
\hline
\end{tabular}

